\title{
Central Bank Balances and Reserve Requirements
}

Simon Gray 


\title{
IMF Working Paper
}

Monetary and Capital Markets Department

\section{Central Bank Balances and Reserve Requirements Prepared by Simon Gray}

Authorized for distribution by Karl Habermeier

February 2011

\begin{abstract}
Most central banks oblige depository institutions to hold minimum reserves against their liabilities, predominantly in the form of balances at the central bank. The role of these reserve requirements has evolved significantly over time. The overlay of changing purposes and practices has the result that it is not always fully clear what the current purpose of reserve requirements is, and this necessarily complicates thinking about how a reserve regime should be structured. This paper describes three main purposes for reserve requirements - prudential, monetary control and liquidity management - and suggests best practice for the structure of a reserves regime. Finally, the paper illustrates current practices using a 2010 IMF survey of 121 central banks.
\end{abstract}

JEL Classification Numbers: E5, E51, and E58.

Keywords: Reserve requirements, central bank, monetary control, remuneration of reserves Author's E-Mail Address: sgray@imf.org

\section{This Working Paper should not be reported as representing the views of the IMF. The views expressed in this Working Paper are those of the author(s) and do not necessarily represent those of the IMF or IMF policy. Working Papers describe research in progress by the author(s) and are published to elicit comments and to further debate.}




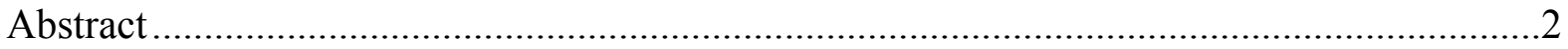

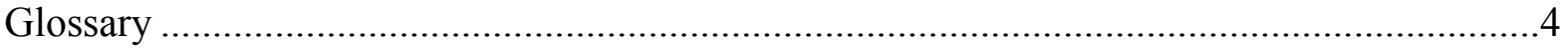

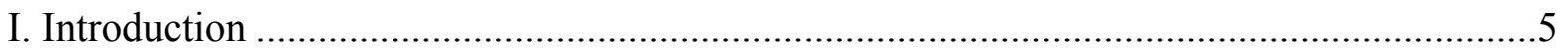

II. The Purpose of Reserve Requirements ...............................................................

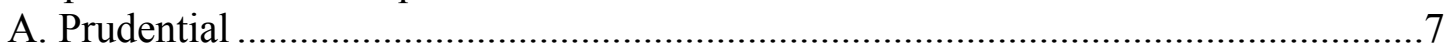

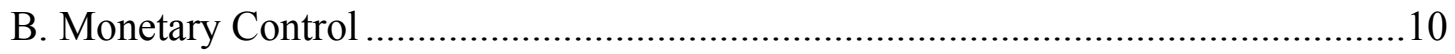

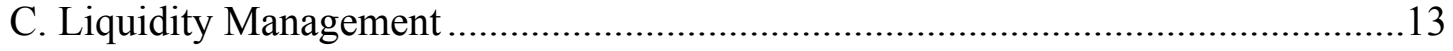

III. Reserves Remuneration as a Policy Signal .......................................................... 15

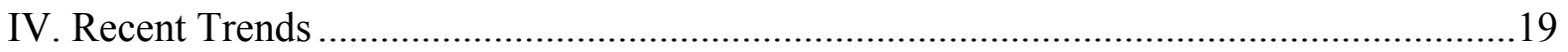

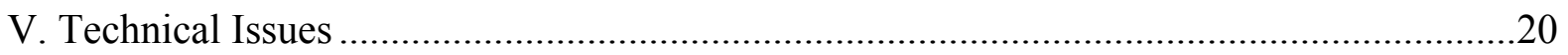

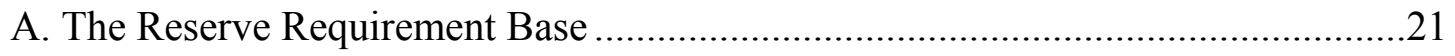

B. Should Reserve Requirements Rates be Uniform? ..........................................24

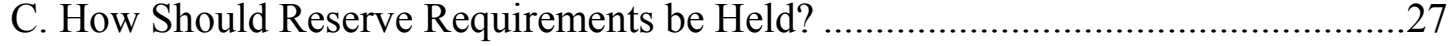

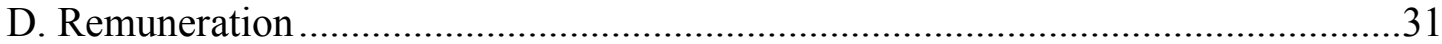

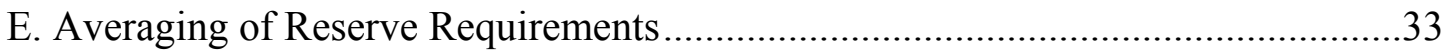

F. Length and Structure of the Reserve Maintenance Period ..................................... 34

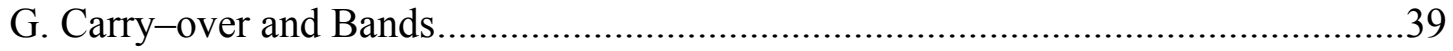

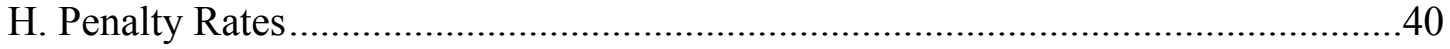

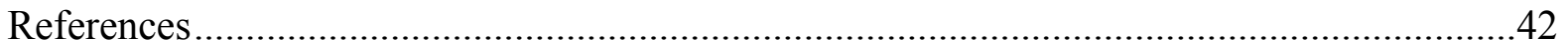

Tables

1. Reserve Requirements by Income Level in 2010 ...................................................20

2. Detailed Reported Breakdown of Reserve Requirements ...........................................25

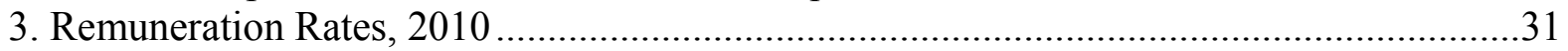

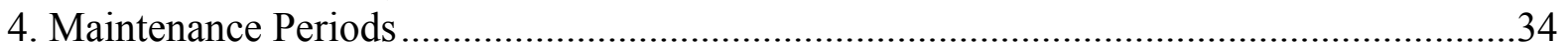

5. United States Reserve Requirements - Historical Changes ..........................................51

6. United States Reserve Requirements - Current Levels ...............................................51

Figures

1. Norway: Short-term Interest Rates......................................................................... 17

2a. United States: Policy Rates and Overnight Interbank Rate ........................................ 18

2b. United Kingdom: Policy Rates and Overnight Interbank Rate .....................................18

3. Levels of Reserve Requirements within Bands ..........................................................20

4. Currency of Denomination of Reserve Requirements on Foreign Currency Liabilities .....30

5. Number of Central Banks that Have a Holding Period Averaging by Region ....................33

6. United Kingdom: Pattern of Reserve Fulfillment ............................................................3

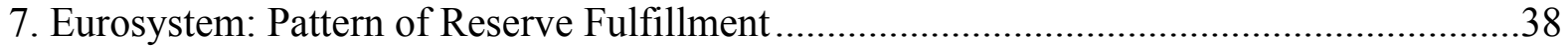

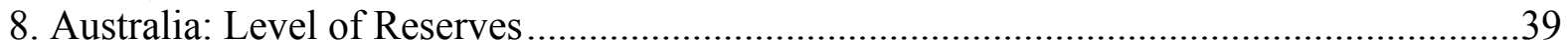




\section{Boxes}

1. Reserve Base and Reserve Ratios

Appendices

I. Impact of Reserve Requirements on Interest Rate Spreads.

II. Reserve Requirements and Liquidity

III. The European Central Bank Reserve Base and Reserve Ratios ......................................45

IV. Bank of England Definition of Eligible Liabilities.........................................................49

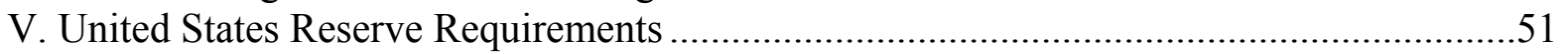

VI. Use by Chile of Reserve Requirements on Foreign Exchange Inflows..............................52

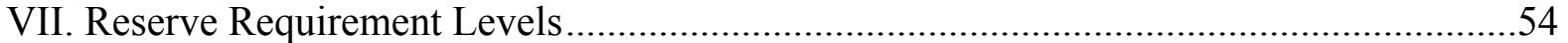




\section{GLOSSARY}

$\begin{array}{ll}\text { ATM } & \text { Automated teller machine } \\ \text { CD } & \text { Certificate of deposit } \\ \text { ECB } & \text { European Central Bank } \\ \text { FFR } & \text { Federal funds rate } \\ \text { GSE } & \text { Government sponsored enterprise } \\ \text { IOAR } & \text { Interest on agreed reserves } \\ \text { IOER } & \text { Interest on excess reserves } \\ \text { IORR } & \text { Interest on required reserves } \\ \text { Libor } & \text { London Interbank Offered Rate } \\ \text { OMO } & \text { Open market operations } \\ \text { RMP } & \text { Reserve maintenance period } \\ \text { RR } & \text { Required reserves } \\ \text { SF } & \text { Standing facility } \\ \text { SONIA } & \text { Sterling overnight interest average } \\ \text { URR } & \text { Unremunerated required reserves }\end{array}$




\section{INTRODUCTION}

1. Most central banks —over 90 percent —oblige depository institutions (commercial banks) to hold minimum reserves against their liabilities, predominantly in the form of balances at the central bank. The role of these reserve requirements (RR) has evolved significantly over time. The overlay of changing purposes and practices has the result that it is not always fully clear what the current purpose of reserve requirements is, and this necessarily complicates thinking about how a reserve regime should be structured.

\section{This paper suggests three main reasons for the imposition of RR.}

- $\quad$ Prudential. In some cases stemming back to the gold standard, when commercial banks' ability to take deposits and issue their own banknotes was constrained by a requirement to hold proportionate reserve balances either directly, or at another bank (eventually the central bank), which in turn held gold reserves. These reserves provided some protection against both liquidity and solvency risks.

- $\quad$ Monetary control. This takes two forms: First, if reserve money cannot easily be increased, ${ }^{1}$ RR may restrict commercial bank balance sheet growth. Second, the central bank could vary the level of (unremunerated) RR in a way intended to influence the spread between deposit and lending rates, in order to impact the growth of monetary aggregates and thus inflation.

- $\quad$ Liquidity management. This may be active or passive. Using RR actively, a central bank can immobilize surplus reserves by administrative fiat, so that the impact of a surplus on bank behavior (low interest rates, demand for foreign exchange) does not in turn lead to inflation or depreciation (both of which involve a loss of value for the currency). Similarly, if demand for reserves exceeds supply, the central bank could lower RR in response. A passive approach can be adopted, if RR can be met on average over a period: short-term liquidity management by the commercial banks is facilitated, with a consequent reduction in short-term interest rate volatility.

3. In deciding the precise structure of $R R$ (if any), it is important for a central bank to be clear what the intended goals are. Since different goals may require different structures, the central bank may need to choose which goals to prioritize. For example, reserve averaging is a powerful liquidity management tool, but giving primacy to this goal undermines the prudential aspect since a bank could, if under pressure, run down reserves for a period and so not have any left when trouble arrived. Similarly, one of the benefits of reserve averaging is that it reduces the need for 'excess', or precautionary, reserves, effectively reducing the demand for central bank balances: this could be an issue if RR are

\footnotetext{
${ }^{1}$ For instance, historically when central bank reserve creation had to be backed by gold, or in a currency board system.
} 
being used as a means of immobilizing surplus reserves. Remuneration of reserves reduces or eliminates a distortionary tax and reduces incentives on the financial system to avoid reservable liabilities, but will also weaken or eliminate the impact of RR on interest rate spreads in the market.

\section{These RR (also known as legal or statutory reserves) are invariably calculated} by reference to a commercial bank's liabilities. RR must be held in the form of a reliable asset: historically, in gold, but now typically in central bank money. Central bank (or "reserve" or "base") money refers to domestic-currency central bank money used in an economy, and is defined as currency in issue ${ }^{2}$ plus commercial bank balances held at the central bank. ${ }^{3}$

\section{There will be some voluntary holding of reserve money in any economy,} regardless of the central bank's policy on RR. In virtually all countries there is a certain level of demand for the ability to settle large--value transactions in central bank money, and this effectively means the banking sector will voluntarily hold reserve (or settlement) account balances at the central bank. The volume of reserves voluntarily held is clearly likely to be higher if such balances are remunerated. It is also likely to vary over time, reflecting shortterm factors (e.g. seasonally high transactions volumes) or longer-term developments (e.g. infrastructure improvements). Some central banks aim to set RR above the voluntarily-held level because this can create a predictable demand for reserves balances. Provided the level is not too high, and RR are remunerated, the distortionary impact may not be significant.

Demanded reserves will be the higher of voluntarily-held required and levels. In a number of countries, the actual level of reserves exceeds the demanded level, sometimes substantially.

\section{In this paper, the term "excess reserves" is used to mean "in excess of required} reserves," whether or not the excess is surplus to demand; and "surplus reserves" is used to mean balances which are above demanded levels. Banks may voluntarily hold excess reserves, but by definition will not want to hold surplus reserve balances; so excess reserves are by definition equal to or greater than surplus reserves. Excess reserves can be easily observed by the central bank: they can be calculated simply by comparing the required level against actual reserve balances held. By contrast, surplus reserves are harder to observe accurately, in part because the demanded level varies from time to time.

\section{Banks' efforts to dispose of surplus reserves will tend to lead to an easing of}

monetary conditions. Either those efforts push down short-term interest rates as banks try to lend out the funds; or because they weaken the exchange rate as banks try to sell surplus

\footnotetext{
${ }^{2}$ Currency in issue is currency in circulation outside the banking system, plus vault cash held by the commercial banks (and sometimes coin, which may be issued by the central bank or the government).

${ }^{3}$ In most economies economic agents will also make substantial use of non-central bank money-transfers of balances held at commercial banks, effected electronically, or in paper form (checks); or the banknotes issued by a foreign central bank ("dollarization").
} 
domestic currency balances. Central banks therefore need to estimate the level of surplus reserves in order to determine what action, if any, is necessary to prevent an unwanted monetary impact. If actual reserves are below demanded levels, the response of banks in bidding for reserve money will imply a tightening of monetary conditions. Central banks can of course counter any undesired tightening by providing reserves to the system.

8. The stance of monetary policy may be signaled by the remuneration rate on excess reserves, rather than by the rate for central bank open market operations or an announced target market rate. This approach is sometimes referred to as a "floor" system, as there is an expectation that short-term market rates will trade around the floor of the interest rate corridor, rather than in the middle.

9. This paper discusses in some detail the differing reasons for requiring or encouraging commercial banks to hold central bank reserves (section II); reviews the use of reserves remuneration as a policy tool (section III); provides data on the current use of reserve requirements by 121 central banks, using a recent IMF survey (section IV); and then explores a range of technical issues relating to such reserves (section V). It concludes:

- $\quad$ The use of RR to support prudential requirements and monetary control is largely outdated, and can be more effectively met, in most cases, by use of other tools. But in some markets, in some circumstances, active use of RR may make sense.

- Central banks should normally manage reserves in an accommodating manner, in order to avoid the unwanted consequences of a surplus or shortage of reserve balances.

- $\quad$ Reserves averaging can be a powerful means of helping the market to cope with liquidity shocks, and so reduce short-term interest rate volatility. The technical construction of reserve averaging systems is important.

- $\quad$ The remuneration rate on excess reserves can be used to signal the monetary policy stance: this is relatively unusual, but may be well suited to central banks facing a structural surplus of reserves or where demand for reserves is particularly hard to estimate.

\section{The PURPose Of ReSERVE REQUiREMENTS}

\section{A. Prudential}

10. RRs ensure that banks hold a certain proportion of high quality, liquid assets. In the days of the gold standard, banks might hold gold - either directly or with another bank- 
as backing for deposits received or notes issued, ${ }^{4}$ but reserves cover could only be partial if banks were to conduct any lending business funded by deposits. This structure of partial reserve cover is sometimes referred to as "fractional banking"-banks held reserve assets equivalent to a fraction of their liabilities - particularly short-term liabilities, where outflows could happen most rapidly and liquidity cover was therefore most important.

\section{Initially the level of reserve cover was voluntary, but over time these reserves were centralized in central banks, which mandated the level of reserve coverage} required. In the United States, from early in the 19th century until 1863 when the National Bank Act was introduced (setting RRs for banks), many banks held reserves - typically, gold or its equivalent - informally with other commercial banks in return for an agreement by that bank to accept their banknotes. ${ }^{5}$ Individuals would be more willing to use notes issued by Bank A if they knew that issuance was backed (if only partially) by reserves, and that at least some other banks would accept those notes; and Bank B would clearly be more willing to accept Bank A's notes if they had some reliable backing. This is similar to ideas discussed by Bagehot in Lombard Street (1863), where he suggests that banks should hold more than enough reserves - essentially, gold or balances at the central bank - to meet likely short-run demand. ${ }^{6}$

\section{Short-run demand-a net drain on the banking system's reserves-could come} from two sources: the need to make payments abroad, or a domestic panic. In the case of an international drain, foreign currency (or gold) is needed, and interest rates may be increased to reverse the drain. In the case of a domestic drain, central bank lending of domestic reserve money is required. In the post gold standard world, domestic currency reserves are only likely to be able to cover domestic liquidity needs. Reserves to cover international needs belong to the sphere of foreign exchange reserves management, where different policy issues arise. ${ }^{7}$

\footnotetext{
${ }^{4}$ Both notes issued - before note issuance became a central bank monopoly - and deposits were liabilities of the commercial bank, which in principle could be converted into gold ('specie') on request.

${ }^{5}$ See for instance "Reserve Requirements: History, Current Practice, and Potential Reform” in the June 1993 Federal Reserve Bulletin, p. 572 et seq.

6 "A good banker will have accumulated in ordinary times the reserve he is to make use of in extraordinary times." At the time he was writing, the Bank of England was de facto the reserve bank (it held gold reserves for the banking system as a whole), but de jure was a private bank with no legislative authority over the system.

${ }^{7}$ Individual commercial banks would not be expected to hold foreign exchange reserves against a country's wider balance of payments needs; this is more properly a central bank function. That said, the recent international financial crisis may suggest that if commercial banks make substantial use of foreign borrowing, there is a need for foreign currency reserves to protect against a 'drain arising from internal discredit', since the domestic central bank cannot lend foreign exchange freely in the same way that is can with its domestic currency.
} 
13. The fractional reserve approach gave added confidence to the use of private sector money (such as notes issued by commercial banks). It was bolstered by the banks' ability, over time, to resort to borrowing from the central bank. Until the $20^{\text {th }}$ century, this was largely informal (Bagehot complains in 'Lombard Street' of the importance of such a role in the United Kingdom being entrusted to the Bank of England without any parliamentary authority or government guidance). In the United States, the creation in 1913 of the Federal Reserve Bank system meant that a reliable central bank could lend "reserves" (here meaning: central bank balances, which could if necessary be converted into gold) to member banks. This form of support is primarily related to liquidity, as it would allow commercial banks, up to a point, to cope with a bank run. But it also has elements of solvency, since the reserves held by the commercial banks with the central bank should be of the highest credit quality.

14. But the prudential and 'safety net' benefits are in most cases now coveredmore effectively - by a combination of supervision and regulation (with appropriate capital adequacy and liquidity requirements), deposit insurance, and standing credit facilities provided by the central bank. Moreover, as discussed below, the prudential role of reserves is substantially weakened where reserve averaging is permitted. In 2010, over 80 percent of central banks permitted at least some element of reserve averaging.

15. Where the prudential (liquidity and solvency) goals of RR can be met more effectively and efficiently with other approaches, the prudential role of $R R$ may be outdated. Central bank balances will still likely form part of the liquidity management of commercial banks, but a standardized administrative requirement on all banks is not obviously the best way to promote this. Supervisors would certainly be expected to count central bank balances as highly liquid assets, and would expect banks — particularly those with important business in the large value payment system of the country - to hold a certain level of central bank balances. But other assets would also likely be included, such as shortterm government securities.

\section{In many countries, banking regulation and supervision is not a central bank}

task. This raises an interesting question: remuneration of reserve balances provides an incentive for banks to hold reserve balances, but may not be the appropriate way to motivate the holding of balances for prudential purposes, since the central bank may not be the supervisor. While remuneration of RR (or an agreed level of reserves, see section II.B) does not have a direct monetary policy impact, a non-central bank supervisor could not require the central bank to pay a certain rate of return on reserves. On the other hand, the central bank as overseer of the large value payment system (this is typically a central bank function) has an interest in ensuring that members of the payment system have sufficient liquiditywhether reserve balances or access to credit (such as the central bank's standing credit facility) - to ensure the risk of disruption to payments is minimized. If RR were used to support payment system liquidity, then logically they should apply to all members of the payment system, whether banks or not. 


\section{B. Monetary Control}

17. The uses of RRs for monetary control are normally described in terms of two channels: the money multiplier, and the impact of RR on interest rate spreads.

\section{The money multiplier and control of credit growth}

\section{The money multiplier approach assumes that banks increase their loan} portfolios until constrained by reserve requirements, on the assumption that the supply of reserves is constrained. If a minimum fraction of commercial bank borrowing needs to be covered by reserves (gold), then the availability of reserves (gold) must necessarily limit bank borrowing, and thereby its capacity to lend. ${ }^{8}$ (Credit funded by non-reservable liabilities would not be so constrained.) Under a currency board system (or the gold - or other specie - standard), reserve money creation is constrained by the requirement that it be backed by specified assets. Central bank purchase of foreign exchange or gold provides an external backing to reserve money; the purchase of government securities may also provide backing, but is closer to secured lending. If reserve creation is constrained, a higher reserve requirement would then necessarily force a reduction in lending, while a lower requirement would permit an increase. But this description does not reflect modern central banking practice. ${ }^{9}$ Once "reserves" comes to mean "balances at the central bank," the central bank can easily accommodate any increase in the demand for reserves - provided banks hold adequate collateral—since it can create them.

\section{Using control over reserve money to guide credit growth in a fiat money system} is in practice an indirect means of using interest rates. Instead of restricting the availability of reserve money completely - an action that could provoke fails in the payment system - central banks in many countries restricted the amount of reserves which could be funded at or around the policy interest rate. Assume for instance that a central bank estimates the market to be short of 100 in reserve balances. It could lend 100 via its OMO at market rates (assuming that market rates are in line with the policy target). Or if it wanted market rates to rise, it could lend only 50 via OMO at market rates, forcing banks to fund the remaining 50 via the standing credit facility. If banks had to borrow larger amounts at the higher standing credit facility rate (the Discount, or Lombard, or Bank Rate) their overall

\footnotetext{
${ }^{8}$ An outflow of gold could force a contraction in lending, as happened in some countries in the 1920s and early 1930s.

${ }^{9}$ Under a currency board system, domestic currency lending may be constrained by RRs; but foreign currency lending is not. The 'barbarous relic' (Keynes, "A tract on monetary reform") of limiting credit to a multiple of available gold is history. ["If we restore the gold standard, are we to return also to the pre-war conceptions of bank-rate, allowing the tides of gold to play what tricks they like with the internal price level, and abandoning the attempt to moderate the disastrous influence of the credit cycle on the stability of prices and employment?.... Advocates of the ancient standard do not observe how remote it now is from the spirit and the requirements of the age. A regulated non-metallic standard has slipped in unnoticed. It exists."].
} 
cost of funding would rise, and this would be passed on to customers. ${ }^{10}$ However, in recent years central banks have increasingly adjusted the policy rate explicitly rather than expecting the market to infer it from the balance of reserves supplied between OMO and a standing credit facility, and taken an accommodative approach to reserve money supply (so that the expectation is that the standing credit facility will almost never be used). This allows a distinction to be made between the monetary policy stance and reserve money (or liquidity) management.

\section{The discussion applies also to situations of a structural surplus of reserve}

balances. The central bank could aim to drain the surplus via OMO, at or around the targeted market rate and change the announced rate if a change in policy stance was required; or drain only part of the surplus via OMO, leaving the remainder to be remunerated at the interest on excess reserves/standing deposit facility rate. The result would be that market interest rates would be expected to fall below the policy rate.

\section{Interest rate spreads and credit}

\section{RRs which are unremunerated, or at least remunerated substantially below} prevailing market rates, should impact the spread between commercial banks' deposit and lending rates. Banks need to set a certain spread between deposit and lending rates to cover overheads and allow for a profit; unremunerated RRs (URRs) add to this spread. The intuition here is simple: if a proportion of assets backing a deposit liability has to be held as non-interest bearing balances at the central bank, then the average interest rate charged by the bank on its other assets must be correspondingly higher than the average rate paid on its deposits. The imposition of URRs will mean that deposit rates are lower than they otherwise would have been, or lending rates higher, or both. Appendix I provides a numerical example of this.

22. An increase in URR is normally viewed as a monetary policy tightening and vice versa; but the impact is not the same as an increase in official interest rates. To the extent that higher URRs lead to higher lending rates, the monetary policy stance is clearly tightened. But some of the impact will be passed through to deposit rates (unless they are at or near the zero lower bound), and it is not so obvious that lower deposit rates represent a monetary policy tightening. Moreover, RR only have a direct impact on institutions subject to the RR regime - typically, banks - and so may have an uneven impact compared with changes in official interest rates, which should feed through more predictably to all financial markets.

\section{The difference in impact between raising policy interest rates and raising URR} does offer potential benefits to the use of URR. An increase in URR has occasionally been

\footnotetext{
${ }^{10}$ If the market expected the central bank OMO to undersupply market needs, the OMO rate would be bid up.
} 
used, depending on the financial market structure, to allow the central bank to tighten monetary policy without encouraging short-term capital inflows. In recent years, a number of central banks have faced capital inflows which put (unwelcome) upwards pressure on the exchange rate and also help to fuel domestic demand, thus putting upwards pressure on inflation. Simply raising short-term (policy) interest rates to counter inflation risks attracting more capital inflows, offsetting some of the effectiveness of such a move. Increasing reserve requirements, however, might increase lending rates (and so reduce demand) without increasing the deposit rates, and so avoid attracting more capital inflows. ${ }^{11}$ The higher URR is a form of taxation, and since it is not matched by expenditure, should reduce net demand.

24. Some central banks have used a marginal URR as a temporary measure to tackle strong credit growth or lean against capital inflows which increase deposits in the banking system. A marginal URR could be set at 100 percent or more: this can quickly drain surplus reserve balances, and imposes a high cost on marginal loans, while having relatively little direct impact on banks which do not increase their balance sheet size. A high marginal URR on non-resident deposits in domestic currency has been used as a form of capital control (Peru used this instrument in 2010, for instance). The term "URR" is also sometimes used to refer to an effective tax on foreign exchange capital inflows; but in this case it is applied to flows of foreign exchange into the domestic currency, regardless of the route, rather than to stocks of deposit liabilities with commercial banks. Appendix VI provides an example of the use of this form of URR, but URRs on currency flows are not otherwise discussed in this paper.

\section{URR on bank deposit liabilities will be less effective in discouraging capital} inflows, if those inflows are not intermediated by banks, but instead are in the form of the purchase of securities - whether government, central bank or corporate securities - in which case the capital inflows will benefit from a generalized increase in borrowing rates. This would indicate that the use of URRs to target particular flows would need to take careful account of the structure not only of current financial flows, but also of the scope for shortterm flows to be re-routed to avoid, or even take advantage of, the impact of a change in URRs.

\section{Changes in URRs tend to be seen as a relatively imprecise means of}

implementing monetary policy. In most countries RRs are not changed frequently-indeed changing them more than once a year is relatively unusual — and normally can only be changed with a lag e.g., from the next reserve maintenance period.

27. In addition, their impact may be limited. Banks and other financial institutions have an incentive to reduce the taxation-impact of URRs by evading them. If URR lead to a disintermediation of the banking sector, pushing business possibly to less-regulated

\footnotetext{
${ }^{11}$ In early 2008, China, India, and Saudi Arabia were among those countries where RR were raised against a background of a managed or fixed exchange rate and rising inflation.
} 
channels, the consequence may be to distort markets and weaken financial stability, rather than to influence deposit and lending rates actually used in the economy. Where reserve requirements are non-binding - if banks hold and are likely to continue to hold excess reserves - their incentive to reduce the impact of URRs is of course reduced. But it is cold comfort if banks do not seek to avoid URRs largely because they have no impact.

28. The use of RR to freeze surplus liquidity is discussed in paragraphs 33-35.

\section{Liquidity Management}

\section{Averaging of reserve balances}

29. “Averaging" means that a bank's average end-of-day reserve balance over a given period (the reserve maintenance period, RMP) must be equal to or above the required level; but that on any individual day it can be lower or higher. If averaging of RRs is permitted, this can be a very effective way of supporting commercial banks' own short-term liquidity management. Averaging can be particularly useful when it is hard for the central bank to forecast accurately all flows across its balance sheet, since averaging creates an intertemporal liquidity buffer to offset errors in the central bank's forecast. If a bank is indifferent whether it holds a reserve balance today or tomorrow, then it should be prepared to lend in the interbank market if rates are above the level expected for the remainder of the RMP (since it would expect to be able to borrow more cheaply later on), or to borrow if rates are low (since it would expect to be able to lend at a higher rate later on). Both actions would tend to keep overnight market rates at the targeted level. But a bank would not borrow when it was expensive, or lend at a low rate, if it could instead vary its reserve level to accommodate swings in liquidity. Since averaging helps to balance supply and demand, it should reduce the impact of short-term (and economically insignificant) liquidity swings on overnight market rates. This liquidity benefit exists whether or not $\mathrm{RR}$ are remunerated.

\section{RR can be used to create a stable 'demand' for reserve balances, and for many} advanced economy central banks this would appear to be the main justification for continued use of RR. The voluntary demand for reserve balances tends to be unstable: it will vary depending on short-term liquidity flows, changes to the structure of the wholesale payment system, or - currently - the impact of economic shocks on precautionary demand. Forecasting voluntary demand in order to manage liquidity accurately would be difficult. But if RR are set substantially above voluntary demand, then the banking system's actual demand for reserves should become very predictable. Prior to the recent financial crisis, this was most obviously done by the Eurosystem. If this is the justification, there is still merit in reviewing the level of RR periodically. Even if there is no interest rate cost - to the extent the IORR equals the short-term policy OMO rate-a high RR level drains a substantial amount of collateral from the market. ${ }^{12}$ If the collateral is constituted by highly-liquid securities, the

\footnotetext{
${ }^{12}$ Assuming there is a structural liquidity shortage, so that the market has to borrow from the central bank.
} 
securities market may be impacted; but accepting illiquid collateral for regular OMO may reduce the incentive for banks to hold and manage well-traded securities and could motivate banks with less liquid assets to bid heavily for central bank funds (possibly influencing the OMO rate).

31. Since the facilitation of liquidity management should reduce short-term interest rate volatility - to the extent that volatility is the product of unanticipated liquidity shocks-it can promote interbank trading and support capital market development. It may appear counterintuitive that averaging might promote interbank trading, since a bank can meet an unexpected shortage today by running down its reserve balance, instead of borrowing on the interbank market. But the short-term buffer provided by averaging means that banks may be more relaxed about making interbank loans, since they should be more confident of their ability to manage short-term liquidity shocks. In practice, the introduction of averaging tends to be neutral to positive to the volume of interbank trading.

32. Section $\mathbf{V}$, sub-section $\mathbf{E}$ provides more detail on averaging and related technical issues.

\section{Sterilizing surplus reserve balances}

33. If there are surplus reserve balances in the economy, increasing the level of unremunerated (or under-remunerated) RRs may seem like a cheap way of sterilizing the impact of the surplus. The alternative - draining through OMO or paying IOERrepresent a cost to the central bank. Central banks are, of course, policy-driven rather than profit-oriented institutions, but concerns about a weak balance sheet and the consequences of running a loss are nevertheless real. Many central banks which have been battling with the management of surplus reserves in recent years feel under some pressure to find instruments which reduce the cost to the central bank, and therefore find increases in URR to be tempting. But increasing URRs tends to encourage financial disintermediation, reducing their effectiveness. This may particularly be the case if reserve requirements are set on a relatively narrow liability base: a restructuring of a bank's liabilities may evade RRs.

\section{Draining surplus reserves via OMO and paying IOER have a different impact} on the market. OMO can drain reserves at term (whether 7 days or three months or longer), and can guide market rates to the middle of a policy rate corridor. IOER leaves reserves balances in a transactions account, and can only set a floor to interbank rates.

\section{During the market turmoil from 2007 onwards, a number of central banks} reduced the level of reserve requirements in order to provide additional free reserve balances to their banking systems. An important benefit of this approach, compared with lending additional funds at the policy rate, is that it does not require any additional collateral to be provided by the banks. Leaving collateral in the market supported interbank activity. 


\section{Voluntary reserves}

36. A small number of central banks do not impose RR. ${ }^{13}$ Where there is no RR, the central bank can allow the market to operate with very low balances (Canada), or use remuneration to motivate banks to hold a reasonable level of reserves (Australia, New Zealand), or agree a contractual level of remunerated reserves, so that while the level of reserves is essentially voluntary, demand within a given period is predictable (the United Kingdom). The level of reserves held by the banking system as a whole is largely a function of the central bank's decision (to the extent it can control its balance sheet); but individual banks have some choice over the level of reserves they hold. If the level chosen by the central bank exceeds aggregate voluntary demand, short-term rates will tend to fall (and vice versa if the level supply falls below demanded levels). Canada and Mexico target a zero overnight reserves balance; this does require frequent OMO to keep reserve balances on track.

37. Where there are no required reserves, the central bank can clearly influence the demand for reserves by the structure of its operational framework. Of key importance is the remuneration rate of reserves. One might expect the opportunity cost also to be affected by the collateral policy of the central bank (assuming here that the market as a whole is structurally short of reserves and so must borrow from the central bank). Consider two possibilities: Central Bank A will accept only government securities as collateral, while Central Bank B will accept any performing asset held by the commercial banks; and assume that government securities earn a lower rate of return than other assets, reflecting their strong credit and liquidity properties. The overall cost of borrowing from Central Bank A will be higher than from Central Bank B, even if they both lend at the same interest rate; and through market arbitrage, we would therefore expect market rates for Central Bank A's currency to be somewhat higher than for Central Bank B. However, if both targeted the same overnight interbank rate, Central Bank A's OMO lending rate would tend to be somewhat lower than for Central Bank B. If the lower OMO lending rate offset the higher opportunity cost of the collateral used, the overall cost of reserve holding would be equalized.

\section{Reserves Remuneration as a Policy Signal}

38. The remuneration rate of excess reserves (i.e., reserves held above RR levels) can be used to signal the stance of monetary policy. This is sometimes referred to as interest on excess reserves, or IOER. The remuneration rate on RR is not normally seen as constituting a

\footnotetext{
13 The 2010 IMF survey showed 9 out of 121 central banks which responded had no reserve requirement: Australia, Canada, Denmark, Mexico, New Zealand, Norway, Sweden, Timor-Leste, and the United Kingdom; additionally, the Hong Kong Monetary Authority does not impose RR.
} 
policy rate, as individual banks have no choice as to whether they hold RR. Remuneration of RR prevents a distortionary impact, but should have no short-term policy effect. ${ }^{14}$

\section{In a system with no $\mathbf{R R}$, there is most commonly a single rate used for}

remunerating all reserve balances. The term IOER is used here for this case too, since all reserve balances are in excess of the zero RR rate. IOER is also used here to include a situation where the rate on IOER and on required or agreed reserves are set at the same level, even if technically there are two rates. An IOER should set a floor to interbank rates. ${ }^{15,16}$ If there is a single rate, it will necessarily be below the overnight interbank rate, since a bank with surplus reserves would have no incentive to lend to another bank at the IOER rate if it could obtain that rate with no risk and by doing nothing. But the interbank rate does not have to be far above IOER. The examples of Australia, Canada and Norway indicate that around $25 \mathrm{bp}$ may be sufficient to motivate trading where perceived counterparty credit and liquidity risk is low.

\section{In Norway, the key policy rate announced is that for remuneration of overnight} deposits. The overnight market rate has for long periods been in the region of $20-25 \mathrm{bp}$ above this level (rather than in the middle of the corridor, currently $100 \mathrm{bp}$ wide), but rising to the top of the corridor in late 2008 reflecting the global financial crisis, before subsiding again (Figure 1).

\footnotetext{
${ }^{14}$ For instance "The interest rate paid on required reserve balances is determined by the Board and is intended to eliminate effectively the implicit tax that reserve requirements used to impose on depository institutions. The interest rate paid on excess balances is also determined by the Board and gives the Federal Reserve an additional tool for the conduct of monetary policy." See U.S. Federal Reserve Board of Governors website.

${ }^{15}$ Strictly speaking, a floor to the rate on overnight transactions between banks which have ready access to remuneration at the IOER rate. Banks trading in offshore U.S. dollar markets, for instance, might not have reserve accounts at the Fed, and so could not access its IOER.

${ }^{16}$ Interest on required reserves (IORR) or on agreed reserves (IOAR) do not set a floor as they are not marginal rates.
} 
Figure 1. Norway: Short-term Interest Rates

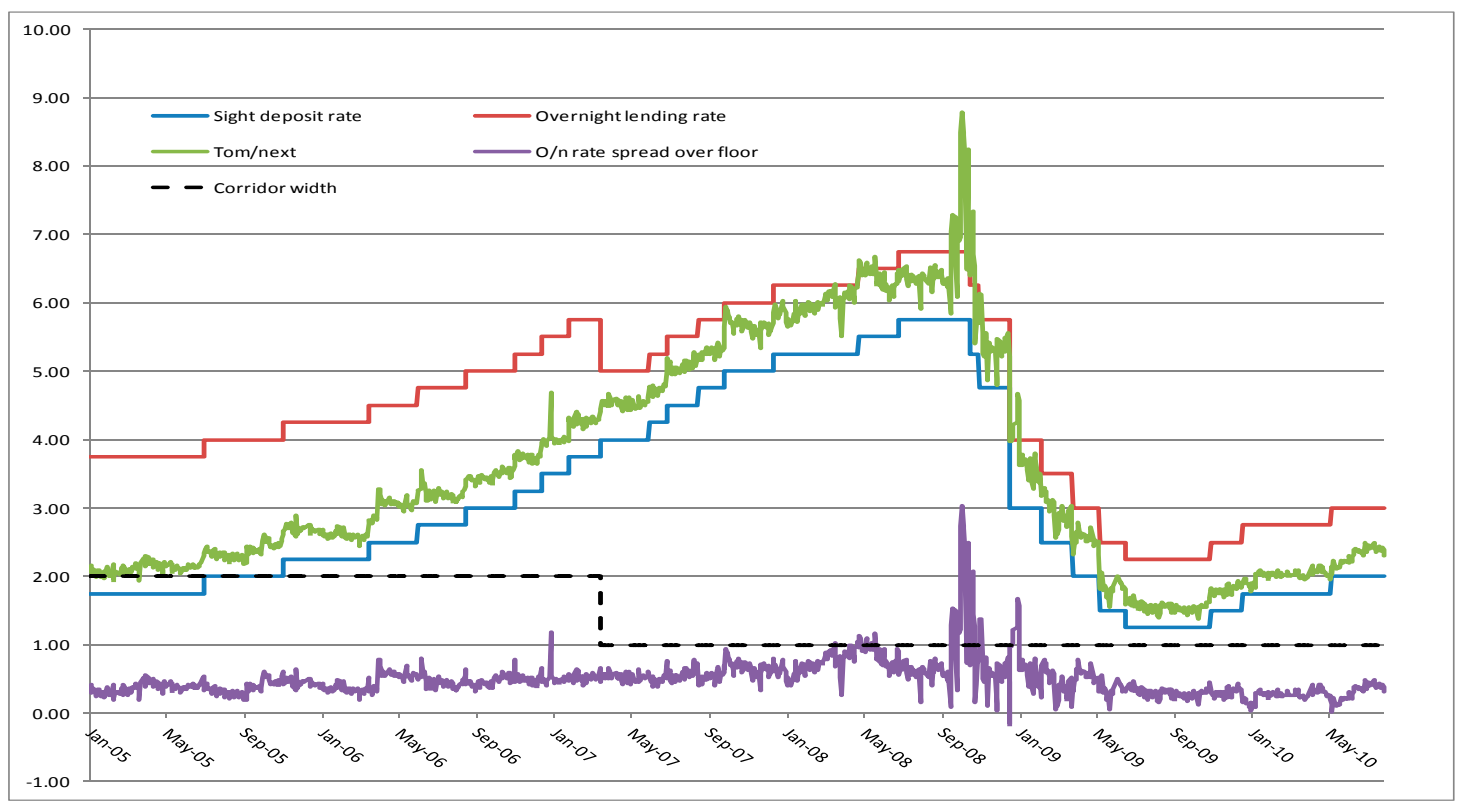

Source: Norges Bank data

\section{In the United Kingdom and the United States at present, the IOER rate has} become the key policy rate: all reserve balances are remunerated at a single rate, and there are no short-term OMO. ${ }^{17}$ [In the Eurosystem, there is a differentiation between IORR and IOER (100bp and 25bp respectively in mid-2010), but the large volume of excess reserves means that it is the IOER which guides short-term market rates.] Figures 2.a and 2.b below indicate that IOER will not necessarily set a floor to targeted money market rates, if these are not pure interbank rates. The effective Federal funds rate (FFR) has been trading below the IOER 'floor' because of the inclusion of GSE trades in the calculation; but the maximum bid rate- - which likely represents genuine interbank trades, has been fairly stable at 12.5-15bp above the IOER rate. In the United Kingdom, the effective sterling overnight rate (SONIA), like the US FFR, is not a pure interbank rate; but Sterling overnight LIBOR and the highest transaction rate in the SONIA data have been around $5 \mathrm{bp}$ above the IOER rate. $^{18}$

\footnotetext{
${ }^{17}$ In the United Kingdom, the Bank of England suspended voluntary reserves targets in March 2009 and remunerates all reserves at the Bank Rate. Remuneration rates on required and excess reserves in the United States were unified from December 2008; GSE reserve balances in the USA are not remunerated.

${ }^{18}$ The 5bp spread over IOER is small. Not all United Kingdom banks have reserve accounts at the central bank, so that Bank Rate does not set a floor even for interbank rates; and some very large transactions with a small spread may influence the average rate (a 5bp marginal return on GBP1 million amounts only to GBP1.37, so that an overnight transaction on less than GBP10 million would scarcely cover the administration costs of undertaking a deal for a marginal gain of $5 \mathrm{bp}$ ).
} 
Figure 2a. United States: Policy Rates and Overnight Interbank Rate

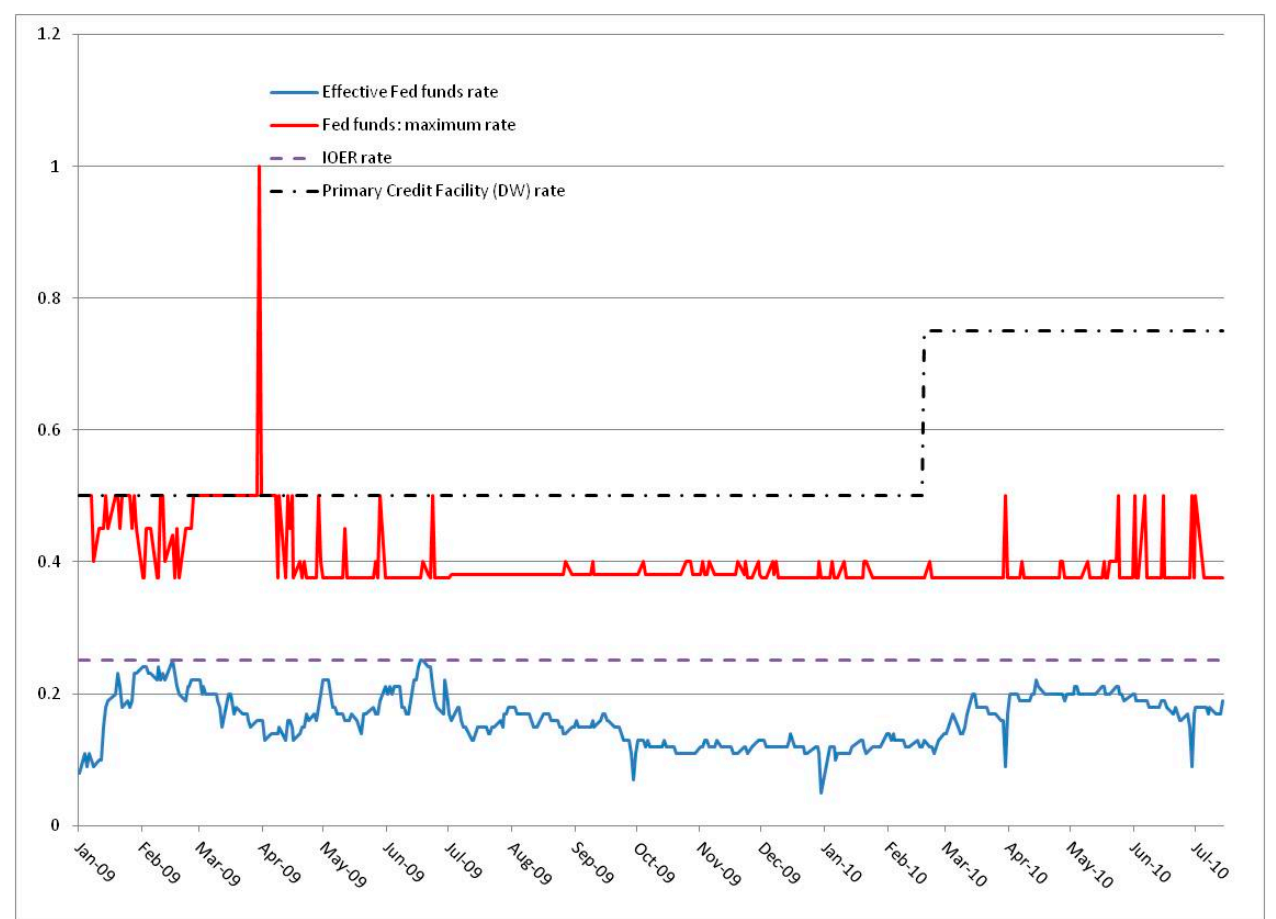

Source: Federal Reserve Bank of New York data.

Figure 2b. United Kingdom: Policy Rates and Overnight Interbank Rate

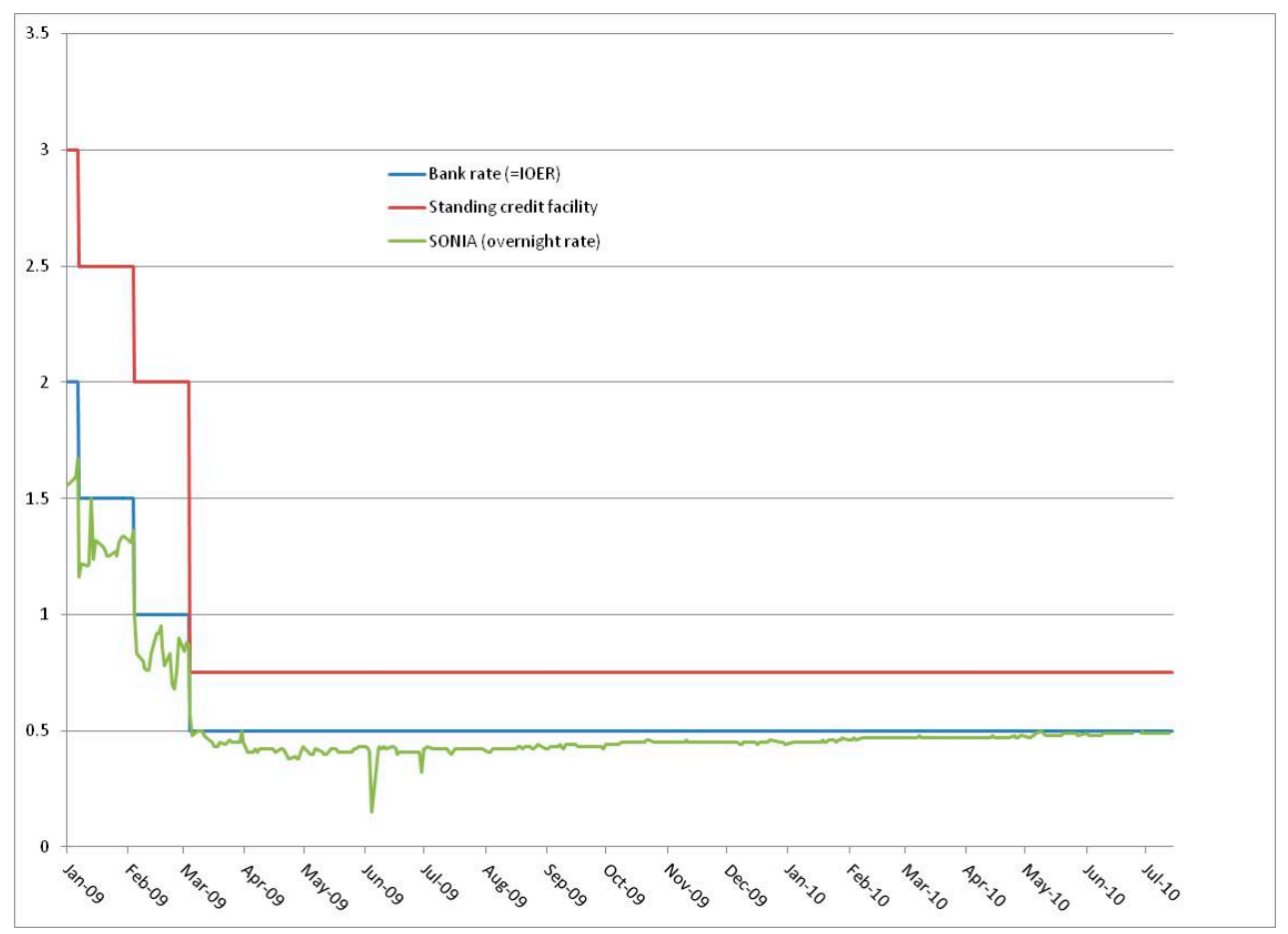

Source: Bank of England data. 
42. In other countries with no $R R$, the key policy rate-the targeted overnight market rate-is the mid-point of the policy rate corridor (the spread between the standing credit and standing deposit facilities). Australia and Canada operate with a 50bp corridor; Sweden has a policy rate corridor of 150bp. In Mexico, the targeted overnight market rate is by definition the middle of a corridor (reserve balances are not remunerated and the standing credit facility is set at twice the target rate); OMO keep the overnight rate close to the target — normally within 10bp.

\section{If a central bank with no RR distinguishes between an IOAR and IOER, it will} need some basis for deciding what volume of reserves should be remunerated at the IOAR (whereas the distinction between IORR and IOER is clear). It may be judged useful to remunerate at (or very close to) the target market rate that level of reserves required by the market as a whole for transactions purposes, since this means that holding these reserves no longer imposes a substantial cost on banks and the incentive to over-economize on reserve holdings is eliminated. ${ }^{19}$ The level could be agreed with banks individually, on a contractual basis (as in the United Kingdom, since May 2006) or informally, either for individual banks (New Zealand) or set for the market as a whole (Australia). The IOAR rate-like IORR - can be set at the mid-point of the policy rate corridor, whereas IOER cannot (because it represents the floor for interbank trades).

44. There is no standard relationship between IORR and IOER. IOER is normally lower than or the same as IORR - most obviously when the IOER is represented by a standing deposit facility rate. But it may be above IORR, as is currently the case in Japan, where RR are not remunerated but excess reserve balances earn $10 \mathrm{bp}$. However, IOAR cannot be set below IOER, since banks would have no incentive to commit to holding a level of reserves that was remunerated below freely-held reserves. ${ }^{20}$

\section{RECENT TRENDS}

\section{The Monetary and Capital Markets Department (MCM) of the IMF conducts} every two to three years a survey of the operational framework of central banks of member countries. The most recent surveys cover the position in early 2008 and early 2010 . Figure 3 and Table 1 indicate the average level and spread of RRs, split by major subgroups. Survey data covering other issues is included in the relevant sections below. (In general, it should be noted that whether a large number of central banks use a particular arrangement is not in itself an argument for its adoption.)

\footnotetext{
${ }^{19}$ If some banks care more about profits than short-term interest rate volatility, they would have an incentive to economize on reserve holdings; whereas the central bank may care more about removing noise from short-term interest rates - because this should make the monetary policy signal clearer and more effective - and may therefore want to structure its operations in such as way as to deliver this. There may be no conflict between the two: Australia and Canada have for some time — pre-crisis—observed virtually zero overnight rate volatility.

${ }^{20}$ It would clearly not make sense to set IOER above an OMO lending rate or the credit SF rate.
} 
Figure 3. Levels of Reserve Requirements within Bands

$$
\text { (in percent of total) })^{1 /}
$$

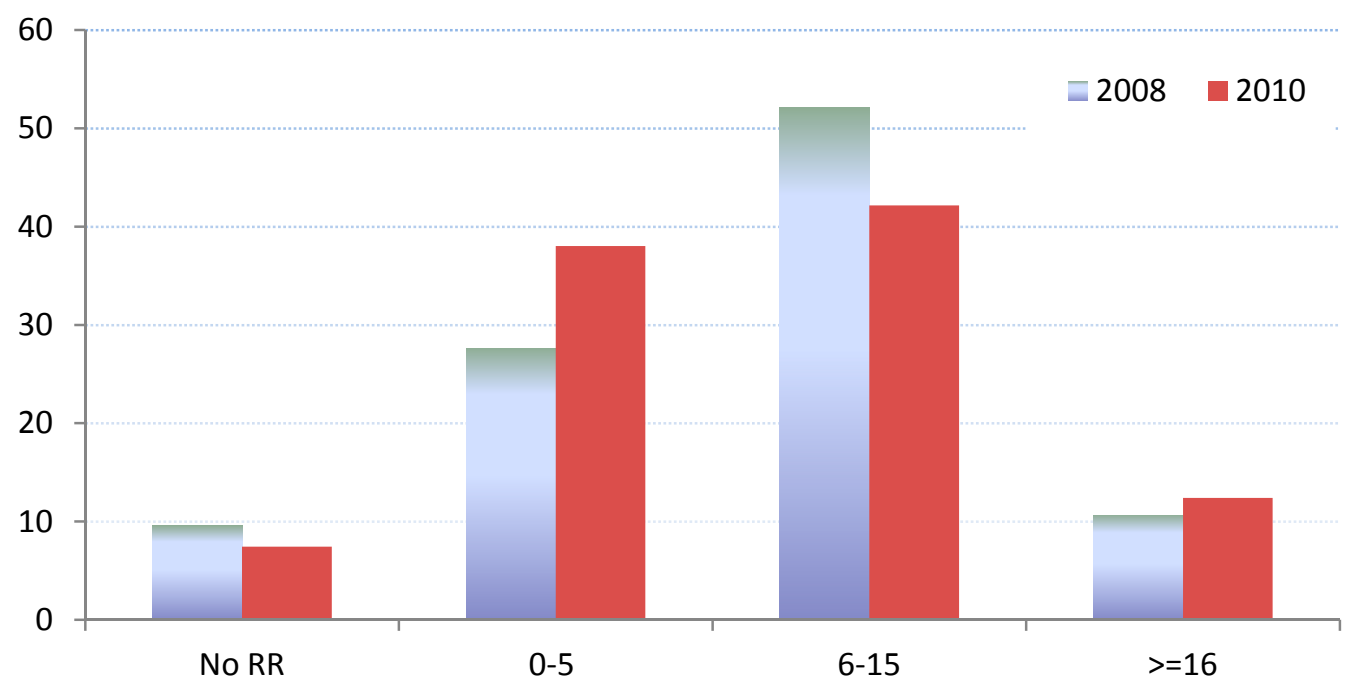

Source: IMF survey of central banks

1/ The figure groups within each band the central banks with a single RR level and those with multiple levels.

\section{Table 1. Reserve Requirements by Income Level in 2010}

\begin{tabular}{|c|c|c|c|c|}
\hline \multicolumn{5}{|c|}{ In percent of Own Income Group for 2010} \\
\hline & No RR & $0-5$ & $6-15$ & $16>=$ \\
\hline High Income & 25.9 & 55.6 & 14.8 & 3.7 \\
\hline Medium Income & 2.8 & 34.7 & 47.2 & 15.3 \\
\hline Low Income & 0.0 & 27.3 & 59.1 & 13.6 \\
\hline \multicolumn{5}{|c|}{ In Percent of Countries in the Region } \\
\hline & No RR & $0-5$ & $6-15$ & $16>=$ \\
\hline AFR & 0.0 & 40.0 & 36.0 & 24.0 \\
\hline APD & 11.1 & 55.6 & 25.9 & 7.4 \\
\hline EUR & 18.2 & 50.0 & 27.3 & 4.5 \\
\hline MCD & 0.0 & 32.0 & 56.0 & 12.0 \\
\hline WHD & 9.1 & 9.1 & 68.2 & 13.6 \\
\hline
\end{tabular}

Source: IMF survey of central banks

\section{TECHNICAL ISSUES}

46. In a number of cases, the choices to be made on technical issues relating to $\mathbf{R R}$ will depend on the goals of the RR. The issues commonly faced by central banks in deciding their approach to reserves are: 
- What should be included in the reserve base? Should it be calculated on a contemporaneous or lagged basis? And as an end-period or period-average figure? (section V.A).

- $\quad$ Should the same rate apply to all banks, and to all types and currency denominations of eligible liabilities? (section V.B).

- Which assets should count towards meeting a reserve requirement? And should they be held in domestic currency, or in the currency of denomination of the relevant liability? (section V.C).

- $\quad$ Should reserve requirements be remunerated? (section V.D).

- $\quad$ Should reserve averaging be allowed, and if so, with what constraints and over what period? (Section V.E).

- $\quad$ The structure of RMPs, reserve carry-overs or bands, and penalties are covered in sections V.F, V.G and V.H.

\section{A. The Reserve Requirement Base}

\section{Inclusions and exclusions}

47. Common practice is to apply $\mathbf{R}$ to commercial bank liabilities with an original maturity of under 2 years, regardless of currency of denomination, but excluding liabilities to other banks subject to the same reserve requirement regime.

\section{As a broad rule, RRs are applied to the liabilities of authorized banks}

(depository institutions). Appendices III-V provide some examples of reservable bases for different central banks. In some 80 percent of cases, RRs apply to liabilities regardless of currency of denomination (though different rates may apply to foreign currency RRs - see below). In most cases, liabilities with an original maturity of over 2 years are excluded, as are interbank deposits (excluded in 90 percent of cases).

49. Some argue that the RR base should reflect as closely as possible the monetary aggregate targeted by the central bank-if there is a monetary target, and RRs are being used to control it. In some countries this would indicate that foreign-currency denominated liabilities should be excluded; and it may also lie behind the practice of excluding long-term liabilities. But it is not clear that there is a tight relationship between the definition of the RR base on the one hand, and a given monetary target and its impact on inflation, on the other. Moreover, the exclusion of foreign currency liabilities is often viewed as encouraging dollarization, since it is likely to make foreign currency deposits and loans 
more attractive to bank customers. No central bank wants to encourage dollarization while maintaining its own currency of issue. ${ }^{21}$ In addition, this approach could not work for central banks which target reserve money, since by definition only central banks issue it, and commercial banks therefore have zero liabilities in terms of reserve money.

\section{Interbank transactions inflate the balance sheets of commercial banks, but provide liquidity and strengthen the interbank yield curve. It is common to exclude} interbank transactions, on the grounds that this would lead to double-counting - RRs would be payable by Bank A on its deposit liability, and by Bank B if Bank A on-lends those funds to Bank B - and can discourage the development of an interbank market. There are two important glosses in support of this definition.

- $\quad$ First, the exclusion should be limited to liabilities to banks which are subject to the same RR regime. ${ }^{22}$

- $\quad$ Second, all liabilities to such banks should be captured, including CDs or other securities issued by a bank. This can complicate the calculation: while it may be clear from statistical returns provided to the central bank where an interbank deposit comes from, statistical returns are less likely to show who holds tradable securities issued by a bank. The ECB requires banks to be able to document when such liabilities are held by other banks, ${ }^{23}$ the Bank of England uses a reporting bank's own claims on other banks, rather than its liabilities to other banks. For the banking system as a whole, this should come to the same thing. Less than 10 percent of central banks include interbank loans in the reservable base.

51. Some central banks exclude repos from reservable liabilities. The ECB for instance applies a zero reserve requirement to repos, regardless of counterparty, whereas the Bank of England only excludes repo transactions with other banks (equating them with interbank loans). Since the United States reserve requirements impact only on transactions accounts, repo liabilities are not included.

\footnotetext{
${ }^{21}$ Dollarization is taken to mean the use of any non-domestic currency, rather than the use of the U.S. dollars per se.

${ }^{22}$ The ECB rules indicate: "Liabilities vis-à-vis other institutions included in the list of institutions subject to the Eurosystem's minimum reserve system and liabilities vis-à-vis the ECB and the national central banks are not included in the reserve base."

${ }^{23}$ The ECB rules indicate: "for the liability category 'debt securities issued,' the issuer needs to be able to prove the actual amount of these instruments held by other institutions subject to the Eurosystem's minimum reserve system in order to be entitled to deduct them from the reserve base."
} 


\section{Timing}

52. Recommended practice is for the RR calculation to be fully lagged, and to be calculated on the basis of the daily average of reservable liabilities in the relevant period, including weekends and bank holidays.

53. Where the $R R$ is seen as controlling a particular monetary aggregate in a precise way, some argue for the use of a contemporaneous calculation of the reserve base. This means that a bank does not know until the end of the reserve maintenance period exactly what the RR will be, although it may be able to estimate it reasonably well shortly before the end of the period. ${ }^{24}$ To reduce the uncertainty, and consequent problems in reserve management, some central banks have used a semi-contemporaneous calculation. This typically means that, for a given two-week maintenance period, the RR is calculated on the basis of liabilities in the two-week period ending at the end of the first week of the maintenance period. ${ }^{25}$

54. Most commonly ( 80 percent of cases) the $\mathbf{R R}$ calculation is fully lagged. Even where monetary aggregates are targeted, few central banks try to control the path of the targeted aggregate precisely on a week-by-week basis. The appropriate lag is then likely to be a case of administrative convenience; and the reporting period does not need to coincide with reserve maintenance periods (RMPs). For instance, banks could report the reserve base for a calendar-month at month end (the date normally chosen for statistical reporting by banks), but with a 15-20 day lag. This data could form the basis for an RMP starting on the second Thursday of the next month but one, and running for four or five weeks (i.e., until the day before the second Thursday of the following month, rather than necessarily for a calendar month).

55. Ideally, the RR base should reflect the average daily liabilities of the commercial bank in the calculation period. Banks may otherwise have an incentive to window-dress their balance sheet for the final day of the reporting period in order to reduce their RR. If an average of daily balances cannot be obtained, ${ }^{26}$ a compromise might be to ask banks to report the average liabilities at the end of each week during the reporting period. Other variants are possible: RRs could be calculated on the basis of the average end-month liabilities over the preceding six months. Over time this should imply the same RR burden, but it would smooth month-by-month changes.

\footnotetext{
24 The U.S. Fed used a contemporaneous system from February 1984 to July 1998.

25 Japan and Korea still uses a semi-lagged RR system.

${ }^{26}$ In some countries, requiring a daily average would constitute an excessive administrative burden on banks. Note that using a daily average does not mean that banks have to report daily; they could report the daily average once every two weeks, or once a month.
} 
56. Some central banks set a de minimis level for the imposition of RRs. This could take the form of saying that banks with a balance sheet below a certain size do not need to report for RR purposes (this reduces the reporting burden as well as the RRs); or that RRs are not payable on the first X million of eligible liabilities.

57. Where RRs are imposed on foreign-currency denominated liabilities, the central bank needs to decide what exchange rate to use. The answer may be straightforward. If the report is provided in domestic currency terms, then the exchange rate applicable to the reporting date is the obvious one to chose. For end-month data, the end-month exchange rate would be used; for period-average reporting, the period-average exchange rate could be used. But if data were reported in the currency of denomination, and additionally the RR was payable in domestic currency (see section $\mathrm{C}$ below for a further discussion of this point), the central bank would need to determine the appropriate exchange rate. Similarly, if banks have liabilities denominated in several foreign currencies but they are paid in a single foreign currency, the central bank will need to determine which exchange rate is used to convert the base currency into the currency in which the relevant RR is held.

\section{B. Should Reserve Requirements Rates be Uniform?}

58. Recommended practice is to use a single $\mathbf{R} R$ rate for all reservable liabilities, except when there are clear and achievable goals in differentiating the rates. A number of central banks operate differentiated rates (discussed in more detail below). In some cases there is a simple differentiation and clear goals; in others the link between current policy goals and multiple rates is less clear.

59. Historically, some central banks have applied differential RR rates to different types of banks. A few central banks still set preferential (i.e. lower) rates for certain banks normally state-owned banks with some form of development role; this would appear to reflect the taxation aspect of unremunerated reserves, and implies a subsidy to those banks which have a lower reserve requirement. But in general it is far preferable for all banks to be subject to the same RR regulations, both for competitive reasons and for administrative simplicity.

60. In some countries, (unremunerated) $R R$ may be reduced in proportion to the commercial bank's lending to a particular economic sector. This is a form of subsidy. Using the RR framework to subsidize directed credit can complicate liquidity management, and is likely suboptimal. 


\section{Uniform by type of liability?}

61. Around 40 percent of central banks use multiple RR ratios (see table 2 below and Appendix VII) depending on the nature of the liability. In such cases, liabilities which are more liquid — notably, sight deposits - carry a higher reserve requirement. This may reflect the original prudential purpose, where reserves would provide some protection against a draw-down of short-term liabilities (or a bank run). It may also carry a notion of monetary control, with transactions accounts differentiated from non-transactions accounts. Appendix V gives an (unusually complex) example of RR in the United States from 196672 , when RR ratios varied depending on the type of institution, the size of liabilities, and the type of liability.

62. The problem with differentiating $R R$ by type of liability is that the rationale may not be clear (or may be outdated), and the practice can (and does) lead to a recharacterization of liabilities. For instance, a deposit may be in a term account for which notice must be given if a withdrawal is to be made. But if the penalty for early withdrawal, or withdrawal at short notice, is waived, then the account might behave in the same way as a sight account, but not be liable to the same RR as a sight account. Or if funds can be transferred same-day from a non-transactions to a transactions account, then customers will be encouraged to hold funds in non-transactions accounts, which avoid RR, but without losing any flexibility in terms of access. The consequence is that such differentiation might not have the intended impact from a prudential or monetary point of view. A rigorous verification regime may be required to ensure the effectiveness of some forms of differentiation.

Table 2. Detailed Reported Breakdown of Reserve Requirements

(in percent of total)

\begin{tabular}{lccccc}
\hline & \multicolumn{2}{c}{ Number } & & \multicolumn{2}{c}{ Percent } \\
\cline { 2 - 3 } \cline { 5 - 6 } & 2008 & 2010 & & 2008 & 2010 \\
\hline No RR & 9 & 9 & & 9.6 & 7.4 \\
one RR 0-5 & 24 & 29 & & 25.5 & 24.0 \\
one RR 6-15 & 39 & 28 & & 41.5 & 23.1 \\
One RR 16 >= & 5 & 8 & & 5.3 & 6.6 \\
Range RR 0-5 & 2 & 17 & & 2.1 & 14.0 \\
Range RR 6-15 & 10 & 23 & & 10.6 & 19.0 \\
Range RR 16>= & 5 & 7 & & 5.3 & 5.8 \\
& 94 & $\mathbf{1 2 1}$ & & $\mathbf{1 0 0 . 0}$ & $\mathbf{1 0 0 . 0}$ \\
\hline
\end{tabular}

Source: IMF survey of central banks 
63. Government deposits should be liable to RR (this is the case in nearly 80 percent of cases; in some countries where there is no formal $R R$ on government deposits, the law specifies that all government balances must be held at the central bank). In a few countries, government deposits in commercial banks are subject to a higher than normal RR (occasionally very high, even up to 100 percent). Government deposits in commercial banks are likely to earn a lower return than the government's cost of funding (e.g., via long-term securities issuance), or the cost to the central bank of draining surplus reserve balances. Large government balances in commercial banks may reflect inefficient cash management, or could be a means of favoring the commercial bank in question to the extent they provide cheap and stable funding. By contrast, centralizing the bulk of government funds is efficient for the state sector (government plus central bank) as a whole. The imposition of high RR on government balances is typically done in order to discourage (or at least offset) the practice of government or quasi-government bodies holding large balances in commercial banks (whether state-owned or private sector), and simulates some of the benefits of a Single Treasury Account.

64. As with higher RR on foreign exchange liabilities, a policy of very high RR on government balances requires that the $R R$ balances are less than fully remunerated, to have maximum impact. The imposition of high $R R$ on government balances does not imply that governments should not use commercial banks: very often they need to make use of them for a range of payment services which cannot be handled by the central bank (e.g., salary payments, pensions). Rather, it indicates that the government should not hold large balances with commercial banks. That said, if governments hold transactional balances with commercial banks - perhaps on a collateralized basis to protect against credit risk - this may simplify liquidity management by the central bank as movements in these accounts do not impact its own balance sheet.

\section{Uniform by currency?}

65. Most central banks impose RR on foreign-currency denominated liabilities as well as on domestic currency liabilities, and use the same rate for both. In a few cases, the central bank imposes a higher RR on foreign currency liabilities. This may be done in order to discourage use of foreign currencies ("dollarization") in the domestic economy, without prohibiting it; and may also reflect a (normally short-term) goal of discouraging capital inflows. In these cases, the higher RR is effectively a marginal tax on the use of foreign currency. As such, it is unlikely to be effective against heavy, short-term speculation, but might have some impact on longer-term speculative pressures. But there are also cases of lower RR on foreign currency liabilities: this has been done to make it easier for the banking sector to attract foreign currency deposits, whether to support the capital account of the country in general, or with the aim of facilitating the provision of export credits (in foreign currency) and so support the export sector in particular.

66. The handling of foreign exchange swaps may complicate the measurement of RR if there is a different rate on domestic currency and foreign exchange liabilities. 


\section{How Should Reserve Requirements be Held?}

67. Recommended practice is to include reserve balances at the central bank (but excluding remunerated term deposits), and possibly vault cash up to a certain limit; but not to include holdings of securities. In some countries there is a case for reserve balances held against foreign currency liabilities to be held in foreign currency.

\section{Which assets are eligible?}

68. Some central banks only allow balances held at the central bank to constitute required reserves. A small extension of this would be to allow very small banks which cannot easily manage reserve accounts at the central bank or obtain central bank funds, instead to hold balances at a larger commercial bank; the intermediary commercial bank would then hold a balance at the central bank on behalf of the small bank.

\section{Around a quarter of central banks also allow vault cash to count towards}

reserve requirements. ${ }^{27}$ In some cases, an upper limit is placed on the extent to which RR can be met with vault cash: for instance, up to 60 percent of the RR can be met with vault cash, and any additional holdings of vault cash are excluded. Two arguments cited in favor of including vault cash are (i) that it is a direct central bank liability just as much as commercial bank balances at the central bank; and (ii) that its inclusion is supportive of banking for rural areas, since rural bank branches typically have to hold more cash (in relation to the size of their business) than city-centre banks. ${ }^{28}$

70. While cash is clearly a central bank liability, it is different to commercial bank balances in that only commercial banks may hold accounts at the central bank (there are a few exceptions to this), but most cash is held outside the banking system. Vault cash also brings with it measurement problems. The central bank knows each day exactly what balances the commercial banks hold; but many commercial banks, especially if they have a large branch network, may not know precisely how much vault cash they hold each day. Some central banks solve the data problem by including vault cash with a lag: holdings of vault cash last month count towards reserve requirements this month.

\section{The growing use of ATMs can also raise tricky definitional issues. Cash is} withdrawn over weekends and public holidays, but banks do not report separately for these days. Reserve balances on the Friday (or whatever day precedes the weekend/public holiday)

\footnotetext{
27 The USA and Switzerland are unusual amongst advanced economies in including vault cash.

28 "The argument in favor of making cash an eligible asset can be turned around: of two banks with the same amount of deposits, there is no reason to favor the one that chooses to engage in cash-intense business to obtain deposits." [Hardy, 1993]. Bagehot, in 'Lombard Street' suggests vault cash is "as much as part of [a bank's] daily stock in trade as its desks or offices" and should not therefore be considered a reserve.
} 
are normally used for the non-working days too. The stock of cash in an ATM at close of business on Friday evening could substantially overstate average ATM cash over the weekend. The solution may be to exclude cash in ATMs from the tally for vault cash, but this too raises measurement problems.

\section{Some central banks are also concerned that holdings of vault cash are not} independently verified, giving banks the ability to misreport with impunity. While this may be true, banks could likewise misreport on the reservable base. As with any other data supplied by banks, audits and periodic supervisory inspections should help to ensure the accuracy of data.

\section{It is less common to allow holdings of foreign currency vault cash to count} towards reserve requirements. They are clearly not a liability of the relevant central bank. If the purpose of RR is purely prudential - holding a certain proportion of liquid assets in case of demand - then foreign currency vault cash should meet the purpose. But it may induce higher than efficient holdings of foreign currency cash, especially if RR are not remunerated. If a bank has to hold foreign currency balances either in the form of account balances at the central bank, or vault cash, it may prefer vault cash since there is no interest loss and the cash is readily available in case of need. (It also avoids any risk that the central bank might use the foreign exchange and not be able to return it on demand e.g., if there is an exchange rate crisis).

\section{A small number central banks count holdings of central bank or treasury bills} towards meeting RRs. If RR are imposed solely for prudential/liquidity purposes, this makes sense, since banks should be able to use these securities to obtain liquidity very quickly if need be. But if RRs are imposed in part for monetary policy purposes, or to drain surplus liquidity, or to facilitate liquidity management by the banking system as a whole, then best practice would exclude holdings of securities: inclusion can complicate liquidity management and distort the yield curve. For instance, assume the banking system holds excess reserves and the central bank sells bills. Banks have an incentive to bid a higher price than non-banks ${ }^{29}$, since their alternative is to meet RRs with a non-remunerated account at the central bank. Excess reserves are not reduced - since the banking system substitutes one reserve asset for another-but the yield curve is pulled down. If the bills were issued by the government, which then spends the funds (the reason, after all, why governments borrow), then excess reserves increase instead of remaining unchanged; and again, the banks have an incentive to bid a higher price than non-banks, distorting the yield curve.

\section{Currency of denomination}

75. Assuming RRs are imposed on foreign-currency denominated liabilities, the central bank needs to decide whether the RR should be held in domestic or foreign

\footnotetext{
${ }^{29}$ In fact, in many countries non-banks are not allowed to buy central bank bills.
} 
currencies. ${ }^{30}$ In practice, in around 30 percent of cases (in 2010), RR on foreign currency liabilities are payable in foreign currency; in some cases, the foreign exchange balance can be held in an account abroad (suggesting a prudential/liquidity purpose for this element of the $\mathrm{RR}$ regime).

\section{An IMF paper $^{31}$ on RRs in sub-Saharan African countries suggested the following:}

"A stable macroeconomic environment and limited currency substitution call for denominating reserve assets, regardless of the corresponding liabilities, in the local currency; this would also facilitate the administration of the reserve balances at the central bank and simplify the central bank's liquidity management....However, exchange rate instability complicates monetary management and makes it difficult for the banks to manage their liquidity when local currency liquidity changes, reflecting the revaluation of banks' foreign currency reserve liabilities."

77. This would suggest that, other things being equal, the neutral position would be to denominate all RR in domestic currency, regardless of the currency of the underlying liability. The question of whether some RR should be payable in foreign currency tends to arise when a sizable proportion of the banking system's liabilities are denominated in foreign currency and there is a history of exchange rate instability (the two are often associated with each other).

\footnotetext{
${ }^{30}$ This issue was explored in depth in Ize (2005).

${ }^{31}$ See Kovanen (2002).
} 
Figure 4. Currency of Denomination of Reserve Requirements on Foreign Currency Liabilities

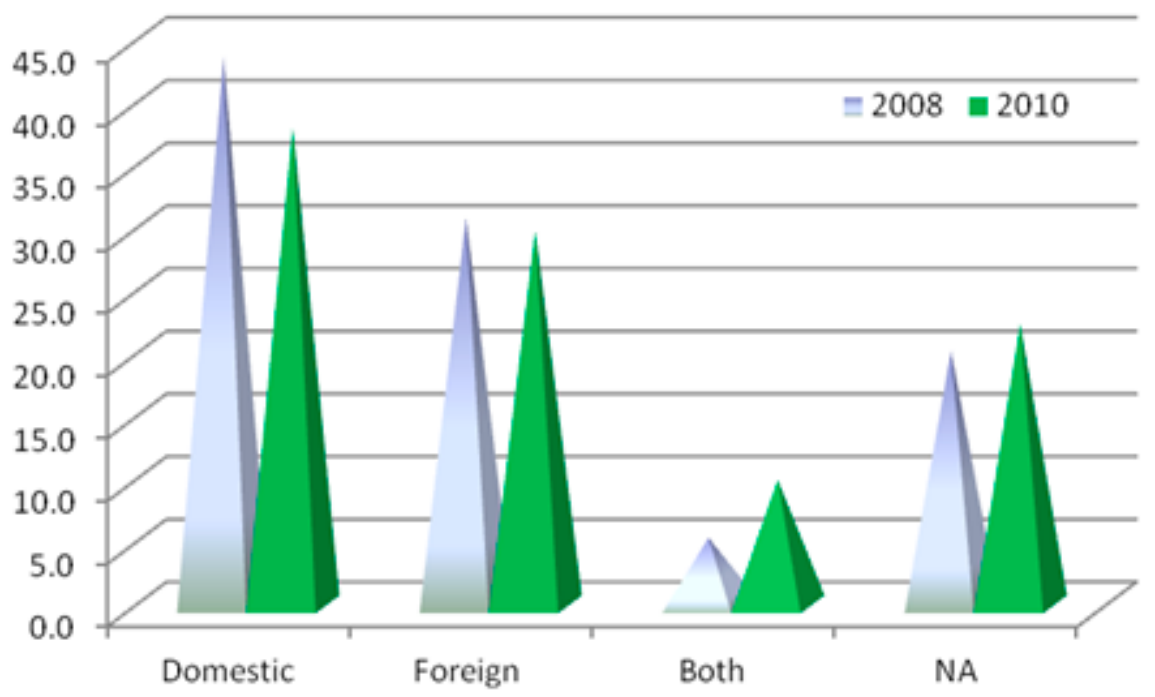

Source: IMF survey of central banks.

78. Domestic-currency denomination of all RR may act as an automatic stabilizer. If a currency depreciates, banks will need to place higher reserve requirements in domestic currency terms in the next maintenance period. The reduced availability of domestic currency may offset some of the depreciation pressures on the currency, either because some banks have to sell foreign exchange in order to obtain sufficient domestic currency balances, or because domestic interest rates rise in response to the reduced supply. If new deposits are received in foreign exchange, the commercial bank may have to sell some of it to obtain domestic currency to meet its RR (unless it already holds sufficient excess domestic currency reserves). Moreover, if the bank had attracted foreign exchange from customers who were betting on a depreciation of the domestic currency, the bank might now lose money if the depreciation occurs, since the RR paid on the foreign currency deposit is denominated in the domestic currency. If banks stand to lose from depreciation, they will have an incentive to discourage customers from engaging in currency speculation.

79. If RR are paid in domestic currency against a foreign currency liability, the commercial bank's open foreign exchange position will be affected. This is more likely to be a problem if the RR ratio is very high. But it does not mean that banks have to have a large open position; simply that they have to take account of this element in the overall management of their balance sheet.

80. Denominating $R R$ in foreign currency does not necessarily remove the currency risk from the commercial bank, unless the central bank accepts $R R$ in a range of currencies. If, for example, a commercial bank accepts deposits in ten different currencies but RR are payable only in the dominant foreign currency, then there will be some crosscurrency exposure. But the alternative - for the central bank to accept RR in ten different currencies —-would be administratively cumbersome. 
81. If $R R$ are paid in foreign currency against foreign-currency liabilities, should the central bank count the foreign currency received as part of its international reserves? If the RR are paid by crediting the central bank's account at a foreign bank, then this will increase both gross and net foreign assets. Although the net foreign exchange holdings of the central bank do not change-since its liability to the depositing bank exactly matches the foreign currency assets received - the foreign currency liability to a domestic bank is not netted off against its foreign assets, because it is a liability to a resident institutional unit. The IMF does however recommend that the central bank's accounts indicate the foreign currency liability to the domestic bank, for purposes of transparency.

\section{A change in the currency of denomination of RRs can have an impact on the} exchange rate: it may be akin to exchange rate intervention. If a central bank has in the past required all RR to be paid in domestic currency, but then changes to require them to be paid in foreign currency where they arise on foreign exchange liabilities, the banking system will receive back some domestic currency and have to give up foreign exchange. This should be expected to put some downwards pressure on the exchange rate. The opposite would happen if the switch is made in the other direction.

\section{Remuneration}

83. Unremunerated $\mathbf{R R}$, especially if set at a high level, are distortionary. If the central bank wishes to eliminate the potential distortion, remuneration of RR should ideally be at or close to the targeted policy rate. However, the majority of central banks do not remunerate RRs (Table 3).

Table 3. Remuneration Rates, 2010

\begin{tabular}{lcc}
\hline & Number & Percent \\
\hline At PR & 7 & 5.8 \\
Fixed margin below PR & 3 & 2.5 \\
Below PR & 25 & 20.7 \\
No Remuneration & 86 & 71.1 \\
\hline & 121 & 100
\end{tabular}

Source: IMF survey of central banks.

84. Whether RR should be remunerated, and if so at what level, will be a reflection of the purposes of the RR. If the goal is to widen the spread between deposit and lending rates, or to drain liquidity "cheaply," then the RR should clearly not be remunerated, at least 
not fully. ${ }^{32}$ If the goal is to immobilize surplus reserves at low cost to the central bank, full remuneration would defeat the purpose. But if their purpose is to support liquidity management through averaging, then remuneration is not only possible, but is preferable, since unremunerated RR represent a distortionary tax on financial intermediation via banks.

\section{If $R R$ are remunerated, the "neutral" rate at which to remunerate is the opportunity cost.}

- Where there is a structural shortage of liquidity and commercial banks borrow from the central bank, the obvious rate to choose is the main lending rate. If the operational framework is effective, this should approximate to short-term interbank rates.

- Where there is a structural surplus of liquidity, it may be less clear what the opportunity cost is. If the central bank is draining some of the excess liquidity at or around a target short-term rate, then the opportunity cost should equate to that rate.

- Remuneration does not have to be exactly at this rate: it could be somewhat lower e.g., 25 bp below the target policy rate. If the central bank does not feel able to use a neutral rate-perhaps because it feels constrained by the overall cost of its operations - it could set the remuneration level at a wider spread below its policy target. A fixed spread below the policy rate should at least mean that the distortion implied by the partial tax on intermediation does not vary when the policy rate varies.

86. If RR imposed on foreign-currency liabilities of the commercial banks are held in foreign currency, the central bank could choose to remunerate them at a different rate to domestic currency $\mathbf{R R}$. If the opportunity cost is seen as the international interbank rate for the relevant currency, RR held in foreign currency could be remunerated at a spread below this. If RR on foreign-currency liabilities are held in domestic currency, and remunerated at domestic market rates, short-term capital inflows might be encouraged if domestic interest rates are relatively high. This would have the same impact as if surplus reserves are drained at market rates via domestic currency OMO.

\section{In addition to RR, the US Fed has historically operated a system of Contractual}

Clearing Balances. Under this system, banks could elect to hold certain balances during an RMP. These balances were subject to full averaging, and set as a band ${ }^{33}$; and while the Fed could not, by law, pay interest on these balances, the balances earned credits which could be

\footnotetext{
32 "From a fiscal perspective, zero remuneration is almost certainly not optimal: zero remuneration implies a tax that varies with the nominal interest rate, which is at best imperfectly controlled and cannot readily be set at the level that is optimal from an efficiency point of view." [Hardy, 1993].

${ }^{33}$ The band is +/- USD 25,000 or 2 percent of the target. Credits were calculated as a proportion ( 80 percent) of the moving average of 3 month Treasury bill yields.
} 
used to offset charges for eligible services provided by the Federal Reserve Banks. The potential problem with such an approach is that the opportunity cost of holding reserves is time-variant, and the demand for reserves may therefore be unstable. Since October 2008, the Fed has been able to remunerate reserve balances.

\section{E. Averaging of Reserve Requirements}

88. Averaging of RRs is an effective way of enhancing liquidity management by commercial banks, and taking the strain off central bank liquidity-management operations. Reserve maintenance periods need to be at least two weeks long.

89. Averaging means that the requirement is assessed against the average end-ofday balances maintained over a specified period in a transactions account at the central bank. The use of averaging is widespread (Figure 5). Rather than having to meet the requirement on a daily basis - in which case the balances may be kept in a separate, nontransactions, account - the requirement is that the average end-of-day balance on the account through a reserve maintenance period must equal or exceed the RR target.

Figure 5. Number of Central Banks that Have a Holding Period Averaging by Region

(Number of countries in the region)

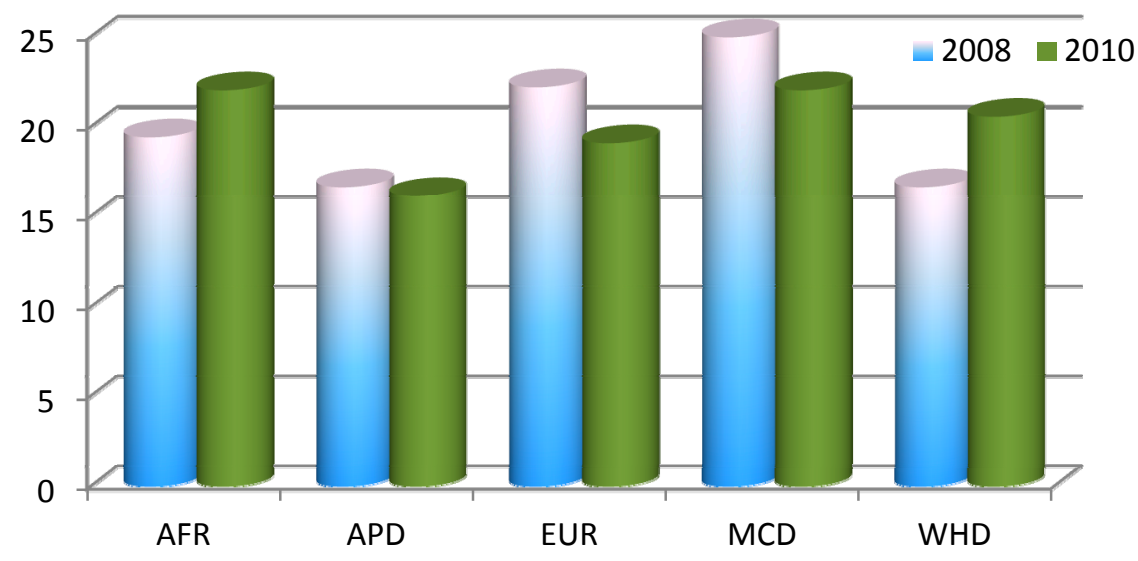

Source: IMF survey of central banks. ${ }^{34}$

90. A key benefit of averaging is that it should help to reduce/largely eliminate volatility in short-term interest rates to the extent this is caused by imbalances in supply of and demand for liquidity. Banks have automatic recourse to their balances at the

${ }^{34}$ AFR - Africa; APD - Asia-Pacific; EUR - Europe; MCD - Middle East and Central Asia; WHD - Western Hemisphere. 
central bank on a daily basis so long as the average level of reserves during the maintenance period at least equals the target level. If swings in liquidity on a given day cannot be accommodated in the market at the expected rate, a bank can allow its reserve balance to take the strain. This should tend to pull market rates towards the targeted policy rate (provided the market expects the central bank to inject/drain the requisite volume of liquidity, at the policy rate, over the RMP as a whole).

91. Partial averaging is used in a number of countries, particularly when the level of RR is relatively high and averaging is first introduced. If $R R$ are 10 percent, the central bank could set a minimum daily level of 5 percent, allowing 50 percent averaging. But if the level of RR is 2 percent (as in the Eurosystem), partial averaging would make less sense. The important factor is that the scope for liquidity management provided by averaging should be large relative to likely daily liquidity shocks. In a system of averaging around zero (practiced in the past by Canada and Mexico), it can be useful to set maximum positive and negative values for end-of-day balances.

\section{F. Length and Structure of the Reserve Maintenance Period}

\section{The length and structure of RMPs matters most if reserve averaging is}

permitted (see section IV.F). In this case, RMPs should be a multiple of 7 days, and should end mid-week; a period of 4 or 5 weeks may be the most effective, and is used by many central banks (Table 4). A longer period would likely weaken a prudential or monetary control function of RR, without providing any significant benefit to liquidity management.

Table 4. Maintenance Periods

\begin{tabular}{|c|c|c|c|c|}
\hline & \multicolumn{2}{|c|}{ Total } & \multicolumn{2}{|c|}{$\%$ of Total } \\
\hline & 2008 & 2010 & 2008 & 2010 \\
\hline No RMP & 8 & 8 & 8.5 & 6.6 \\
\hline Between $1-7$ days & 25 & 25 & 26.6 & 20.7 \\
\hline Between 8-14 days & 16 & 27 & 17.0 & 22.3 \\
\hline$>15$ days & 41 & 57 & 43.6 & 47.1 \\
\hline Varies & 4 & 4 & 4.3 & 3.3 \\
\hline & 94 & 121 & 100 & 100 \\
\hline
\end{tabular}

Source: IMF survey of central banks.

\section{RMPs are most easily manageable if made up of multiples of 7 days; most} central banks find that, in practice, at least a 14 day RMP is needed if banks are to be able to benefit from averaging. One week is not long enough for averaging to be effective. Five or six working days are just too short for banks to make much use of the inter-temporal substitution. Moreover, for central banks trying to forecast liquidity within the RMP in order to keep commercial bank balances at around the targeted level, a period of one week is too short to provide much of a buffer. Two weeks is better; a 4 to 5 week period may be 
optimal. ${ }^{35}$ Periods longer than one month are exceptional. ${ }^{36}$ A lot of transactions have a monthly cycle - government and other salary payments, pension payments, a number of tax flows. It may prove much easier to forecast the transaction values for the month, than to know in which week they will occur. Some central banks are concerned that a one-month period is too long-whether because it might give commercial banks too much scope to speculate or play games or because it could lead to excessive swings in liquidity balances and prove disruptive. But in practice, a one-month period appears to work well. Where this is a concern, it can be managed by partial-averaging and by determining the pattern of reserve fulfillment.

94. The Eurosystem and the Bank of England set RMPs to run between the dates on which monetary policy decision meetings ${ }^{37}$ are held, and in addition use a 7 day maturity for OMO conducted at the policy rate. This means that policy-rate operations do not overlap policy decisions, and liquidity management by the banks is not, therefore, affected by speculation about future rate changes. That is not to say that RMPs have to be as long as the gaps between policy meetings - in some countries these are held quarterly, rather than roughly monthly - but that it is useful to avoid either RMP or policy-rate OMO overlapping the policy decision date, and to avoid policy-rate OMO overlapping RMPs.

\section{Weekends and public holidays should be counted in the calculation of reserve} averaging. Excluding weekends and public holidays is likely to lead to interest rate distortions: banks will be less willing to borrow reserve money over a weekend, if they pay interest for three days but only one day counts towards reserve requirements, and this will cause fluctuations in short-term rates which have no economic value.

96. It is normally best for RMPs to end in the middle of the working week. This does mean that the RMP needs to consist of a multiple of 7 days, rather than being a calendar month (or in the case of a few countries, half a calendar month). The reason is that liquidity forecasting is easier for a mid-week day than the day before or after a week-end. If the central bank can forecast liquidity more accurately on the final day of the RMP (when averaging can no longer be used), it will be easier to avoid end-period spikes in short-term rates. By construction, if end-period rate spikes can be reduced, then short-term rates during the preceding days of the RMP are more likely to be stable. As public holidays in many countries tend to fall on the day before or day after a weekend, Wednesday (in countries observing a Saturday-Sunday weekend) is better than Tuesday or Thursday.

\footnotetext{
${ }^{35}$ If the period is set to end on the first Wednesday of the each month, then depending on the calendar the RMP will vary between four and five weeks throughout the year.

${ }^{36}$ Argentina introduced a 3 month averaging period to cover the year end - when liquidity management in most countries is more difficult than normal.

${ }^{37}$ Meetings of the Governing Council and the Monetary Policy Committee respectively.
} 
97. Liquidity is easier to forecast midweek because of the following:

- $\quad$ Currency in circulation tends to rise on the day before the weekend, and fall back the day after, and periods of greatest change are typically hardest to forecast;

- $\quad$ Checks issued over the weekend will tend to be cashed on the first day or two after the weekend, increasing payments flows then;

- $\quad$ Repeated transactions which are set for a regular date during the month (e.g., pensions or state-sector salaries might be payable on the $20^{\text {th }}$ of each month) cannot be made on the weekend, and so fall more often on the days either side of the weekend than on a midweek day;

- $\quad$ Foreign exchange transactions with a $\mathrm{T}+2$ settlement cannot be settled on the weekend and so fall more often on the days either side of the weekend than on a midweek day.

98. If averaging is not permitted, the precise length of the RMP may be more a matter of administrative convenience. A one calendar month period may strike the best balance between avoiding frequent, but economically meaningless, adjustments, while maintaining a reasonably close link to the actual balance sheet of commercial banks. A 6 or 12 month period would tend to weaken any monetary policy function.

\section{Pattern of reserve fulfillment}

99. The pattern of reserve fulfillment is most often determined by the central bank, as net supplier/drainer of liquidity; but it can be influenced by the banks, by the way they as a group participate in central bank liquidity operations. Most central banks aim, though by no means always succeed, to supply/drain reserves evenly throughout the RMP. This is particularly noticeable with the ECB and the Bank of England, which both operate 4-5 week RMPs and conduct weekly liquidity auctions. Neutral allocation of liquidity at an auction would mean that at close of business on the day before the next operation, the cumulative average reserves balances of the system as a whole should be in line with the target balance for the whole RMP. In Figure 6 below (using the United Kingdom data), the vertical lines indicate days on which liquidity auctions were held; the horizontal lines indicate the reserves target for the RMP. It can be seen that the day-to-day balances show sharp, but regular (and so predictable) swings; but the cumulative reserves balance within each period is reasonably close to the RMP target at the end of each week. The aim is not to bring it back to target on the day of the operation, but to enable banks in aggregate to 
accumulate reserves evenly from week to week over the maintenance period. ${ }^{38}$ This assumes that banks have no particular pattern of demand.

Figure 6. United Kingdom: Pattern of Reserve Fulfillment

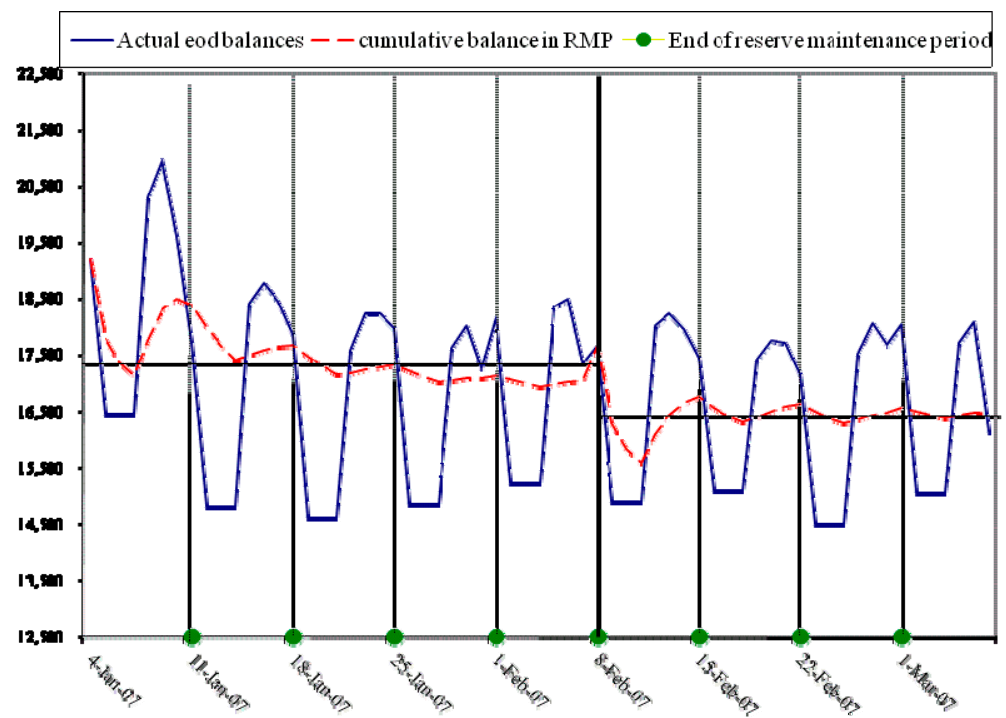

Source: Bank of England data.

100. Figure 7, for the Eurosystem, indicates the same 'neutral' profile until August

2007. But following the onset of market turmoil, the Eurosystem decided to skew the provision of reserves, oversupplying in the first two weeks of the RMP in order to give the markets more confidence about the availability of liquidity, and offsetting this towards the end of the period.

101. In both cases, it was possible for the central bank to determine the pattern of fulfillment provided bids for liquidity at each auction were equal to or exceeded the planned supply. Similarly, if a central bank is draining liquidity, it could choose to drain more than a 'neutral' amount provided the demand for the short-term asset being provided (a short-term bill or deposit, a repo or a swap) exceeds the targeted volume. It is always possible to supply/drain less than the market demand (provided the central bank is prepared to accept the consequences for short-term yields).

102.

38 “The Bank seeks to provide sufficient reserves via its OMOs to enable reserves scheme members in aggregate to accumulate reserves evenly from week to week over the maintenance period. If the Bank over or underprovides reserves because of an error in its liquidity forecast, it makes an adjustment in the subsequent scheduled short-term OMO within the maintenance period, including if necessary the routine fine-tuning OMO on the final day of the maintenance period." Bank of England Red Book, January 2008www.bankofengland.co.uk/markets/money/publications/redbookjan08.pdf. 
Figure 7. Eurosystem: Pattern of Reserve Fulfillment

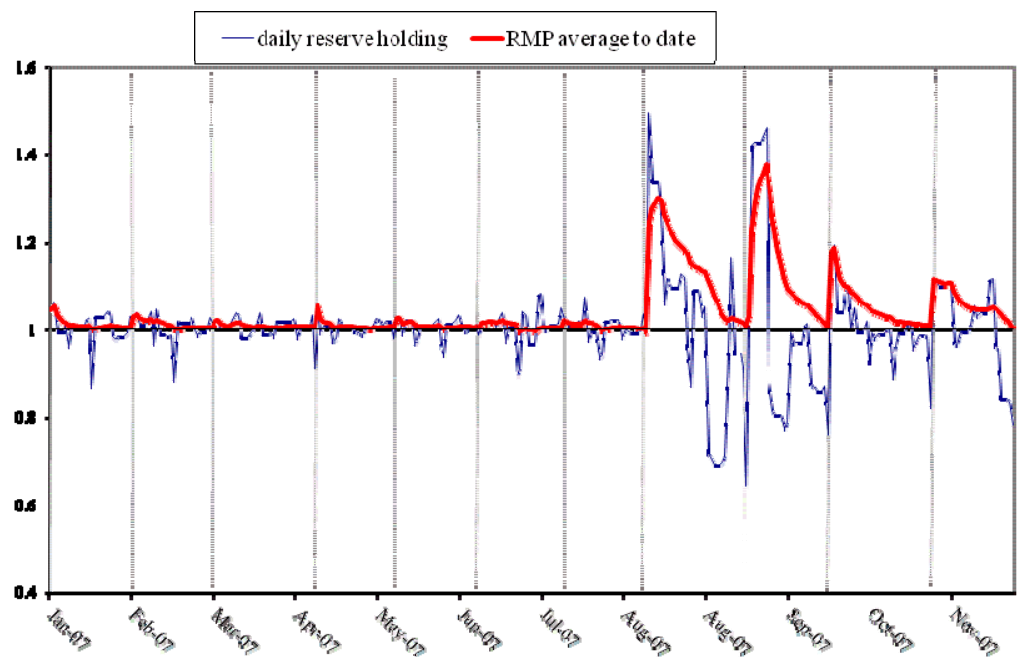

Source: European Central Bank data.

103. If the central bank operates daily, or most days, then it can each day respond to market demand and so be more accommodative to short-term changes in market demand for liquidity — as long as actual demand can be monitored. Some central banks - such as the Reserve Bank of Australia (RBA), the Bank of Canada, the Bank of Japan and the United States Fed - track events which will influence short-term demand, such as large payment days, quarter ends, days on which a large bond offering is being made, as banks typically prefer to hold larger liquid balances on such days. As the Bank of Canada normally targets virtually zero reserves, it needs to operate daily to keep banks on target. In Australia, banks effectively hold voluntary reserves, ${ }^{39}$ which are remunerated at the standing deposit facility rate ( $25 \mathrm{bp}$ below the policy rate). As they are not required reserves, there is no RMP; but the RBA aims to keep balances at around the level which it has observed in practice to smooth day-to-day liquidity shocks without disturbing short-term interest rates. Prior to August 2007 (when the global financial crisis impacted markets), the level was around A \$750-800 million for several years; but as indicated in Figure 8, the volume and variability of demand changed substantially from the outset of the global market turbulence.

${ }^{39}$ Exchange Settlement Accounts (ESA) balances. 
Figure 8. Australia: Level of Reserves

(in millions of $A \$$ )

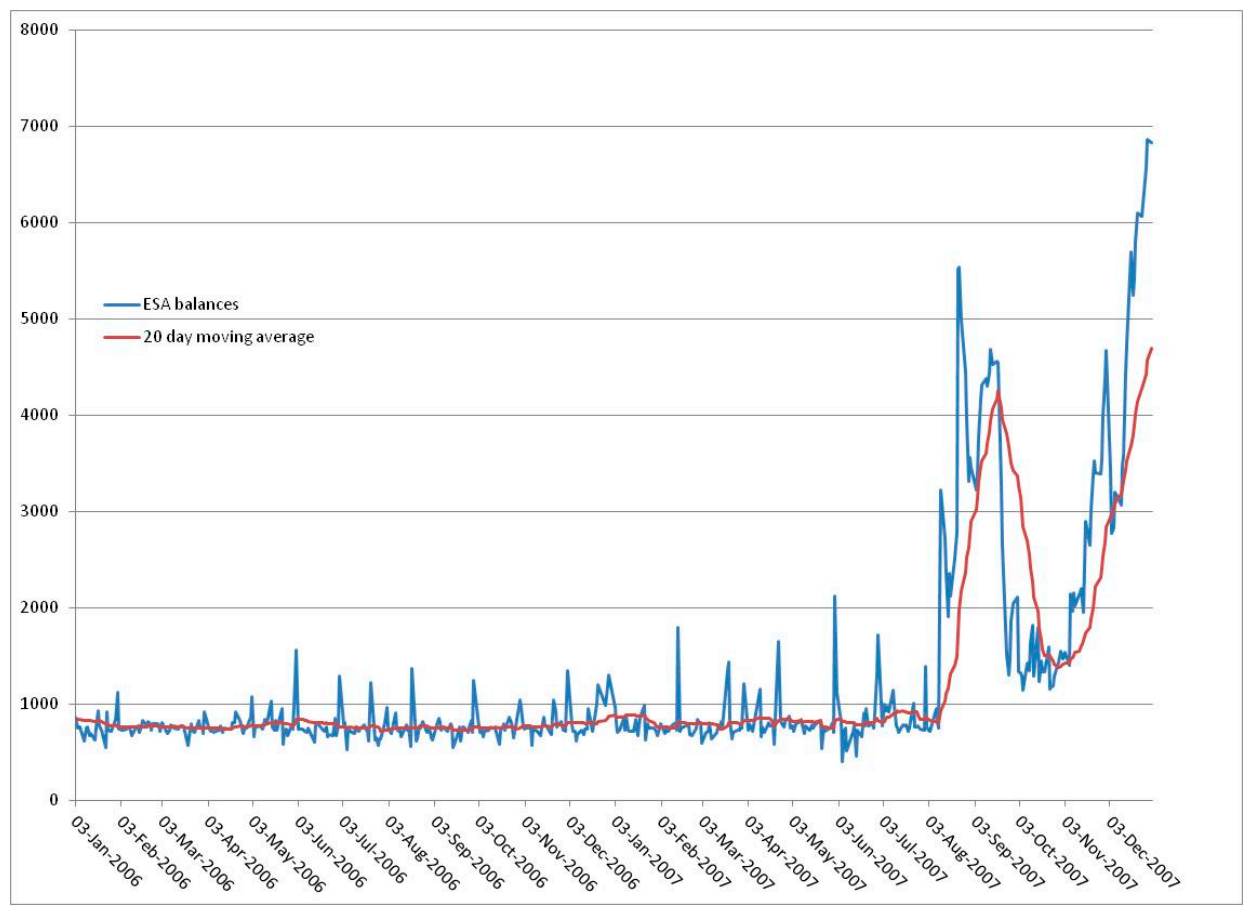

Source: Reserve Bank of Australia data.

104. Where RR are held in domestic currency and averaging is practiced, it is clear that the RR will be held in a transactions account, rather than frozen for the RMP. But it may be less clear what should happen if RR on foreign currency liabilities are paid in foreign currency and averaging is permitted. What sort of transactions facilities might a central bank offer for foreign-currency accounts? The answer may depend on administrative capabilities and charging policy. The central bank presumably would not want to take on a commercial banking function; but it banks are to meet foreign-currency denominated RR, they must have the ability to make transfers to/from correspondent accounts abroad; and if averaging of such an account is to be meaningful, it must be possible for the commercial bank to effect transactions across that account during the RMP. If the banking department of the central bank has capacity to handle a large number of cross-border transactions, and can pass on the costs to commercial banks, it could handle a reasonable amount of business. But it may want to set charges in a way which gives an incentive to commercial banks to use normal commercial channels where possible.

\section{G. Carry-over and Bands}

105. A small carry-over, or use of a target range, can be useful in reducing interest rate spikes at the end of a reserve maintenance period. 
106. It is impossible for a central bank to forecast liquidity flows completely accurately; the banking system as a whole will finish each maintenance period with either a surplus or a deficit of reserves. If there is a small surplus, it may be insignificant; and indeed some banks target a small surplus, as they would prefer to be marginally above the target level and forego interest on a small balance, than run below and be forced to access a penal borrowing facility (for stigma reasons more than cost). Some central banks include in the design of the RR system mechanisms to allow for the uncertainty.

107. The most common is the carry-over facility. A surplus or deficit-within predefined limits — can be carried over to the following maintenance period. For instance, if a bank has an average target of 100 and holds on average only 99, it could agree to target an average of 101 in the following RMP rather than paying a penalty.

108. The Bank of England introduced the concept of a target band for the RMP. Initially, when the system of voluntary contractual reserves was introduced in May 2006, the band was set at $+/-1$ percent, but following the market turmoil from August 2007 was increased. Even a figure of $+/-1$ percent may in fact provide more flexibility than banks normally need. In a four-week (28 day) RMP, assume that the central bank aims to provide the level of reserves that will keep the system as a whole on target at the end of each week. Since it can make corrections each week for any forecast errors in the previous week, and conduct a fine-tuning operation on the final day of the RMP (as in standard in the UK), then it should be able on the last day of the RMP to correct for any errors on the first 27 days. In this case, $+/-1$ percent on average equates to nearly 30 percent of the target for the final day.

\section{H. Penalty Rates}

109. If a commercial bank fails to meet its $\mathbf{R R}$, it is normal to charge a penalty interest rate. This rate should normally be higher than the standing credit facility rate. In part this is because a shortfall is not collateralized, whereas borrowing from the central bank to meet RR would require collateral. Since the central bank wants to encourage banks to use its formal operational framework and meet the RR target, rather than simply having a shortfall on RR, it should be cheaper for a bank to use the formal framework. Moreover, if the central bank wants commercial banks to have a balanced incentive to hit the RR targetneither holding an excess nor a deficit - the logical rate to charge, provided excess reserves are not remunerated, is two times the policy rate. The argument is that excess reserves are unremunerated, so that the opportunity cost of holding an excess is roughly equal to the policy rate. If a bank has a shortfall, it may be assumed that it could have earned around the policy rate on the funds employed elsewhere (or saved that rate by not funding itself), and so should pay twice the policy rate in order for the net cost of a shortage also to be equal to the policy rate. A number of central banks set rates on this basis.

110. If the banking system as a whole fails to hold sufficient reserve balances because of a central bank error (for instance, if the central bank's liquidity forecast was inaccurate), then it is unreasonable to penalize the banking system. In this case, penalties 
may be waived. But if the system is short because it failed to take advantage of the opportunity to borrow from the central bank e.g., via OMO, or because it bought foreign exchange from the central bank, then applying the penalty should provide appropriate incentives to the system. 


\section{REFERENCES}

Hardy, Daniel: April 1993, "Reserve Requirements and Monetary Management: An Introduction," IMF.

Ize, Alain: March 1995, "Reserve Requirements on Foreign Currency Deposits," IMF MAE OP/95/1.

La Conducción de la Política Monetaria del Banco de México a través del Régimen de Saldos Acumulados 1995-2003.

www.banxico.org.mx/polmoneinflacion/didactico/regimenPM/notasTec/SaldosAcum ulados.pdf

Obrien, Yueh-Yun (2007): Reserve Requirement Systems in OECD Countries.

Kovanen, Arto: 2002, "Reserve Requirements on Foreign Currency Deposits in SubSaharan Africa-Main Features and Policy Implications,” IMF WP/02/65. 


\section{APPENDIX I. IMPACT OF RESERVE REQUIREMENTS ON INTEREST RATE SPREADS}

111. It is generally accepted that the imposition of unremunerated RR impacts the spread between deposit and credit interest rates by financial intermediaries (primarily commercial banks) which have to pay the RR. Most simplistically, if the RR were the only factor causing the credit rate to be higher than the deposit rate, then the ratio between credit and deposit rates would be equal to the inverse of (1- reserve requirement ratio). As the RR ratio increases, so does the spread.

\begin{tabular}{lccc}
\hline ASSETS & \multicolumn{1}{c}{ LIABILITIES } \\
\hline Loans & $90 @ 10 \%$ & Deposits @ $9 \%$ & 100 \\
Reserve & $10 @ 0 \%$ & & \\
Requirements & & & \\
Interest income & 9 & Interest expense & 9 \\
\hline
\end{tabular}

Deposit rate $(9 \%)=$ Credit rate $(10 \%) *[1-\mathrm{RR}$ ratio of 0.90$](0.9)$

\begin{tabular}{lclc}
\hline ASSETS & & LIABILITIES & 100 \\
\hline Loans & $75 @ 10 \%$ & Deposits @ $7.5 \%$ & \\
Reserve & $25 @ 0 \%$ & & \\
Requirements & & & 7.5 \\
Interest income & 7.5 & Interest expense & \\
\hline
\end{tabular}

Deposit rate $(7.5$ percent $)=$ Credit rate $(10$ percent $){ }^{*}[1-\mathrm{RR}$ ratio of 0.25$](0.75)$

112. Of course, many other factors influence the spread. Banks need to target a profit, and therefore need to cover overheads and cost of capital. Importantly for some central banks considering how a change in RR might impact the interest rate spreads in their domestic currency markets is the extent of idle balances held by commercial banks. If the RR is 10 percent, but banks hold unremunerated central bank assets (currency and balances on account) equivalent to 15 percent to 20 percent of liabilities because there is excess liquidity in the market and therefore no alternative investment for the market as a whole, then a small change in the RR ratio - say to 8 percent or 12 percent - might have no impact on the spread. It will simply mean that excess reserves change from 5 percent to 10 percent of banks' liabilities to 3 percent to 8 percent (if RR are increased) or 7 percent to 12 percent (if RR are reduced).

113. In markets where there is substantial excess liquidity, the central bank should not therefore expect interest rates to respond significantly to changes in RR until the point at which excess liquidity is substantially drained from the system. At that point, market rates could react very sharply. 


\section{APPENDIX II. RESERVE REQUIREMENTS AND LIQUIDITY}

\section{Liquidity}

\section{Liquidity is a measure of the ease with which fractional reserve banks can meet} the demand for withdrawals by their depositors. This requires that banks maintain an adequate amount of cash on hand or the ability to readily acquire such cash. It was initially thought that requiring banks to maintain a stated level of reserves (defined throughout the paper as vault cash and deposits with the central bank) would be a good way of ensuring adequate bank liquidity. This view of the function of reserve requirements has frequently been ridiculed in recent years because the act of requiring banks to maintain a given level of reserves to a large extent deprives those reserves of their liquidity. Reserves that banks are required to maintain are no longer available to be paid out to the bank's customers. However, this point is often overstated. The liquidity of required reserves will depend upon the length of the accounting period, the penalty for failing to meet the requirement, the level of the requirement, the assets used in satisfying the requirement, and the base upon which the requirement is calculated.

(From "The Use of Reserve Requirements in Developing Countries", Warren Coats, November 23, 1976). 


\section{Appendix III. The European Central Bank Reserve BaSe And ReServe Ratios}

(Source: "The implementation of monetary policy in the Euro Area," ECB, November 2008.)

115. The reserve base of an institution is defined in relation to elements of its balance sheet. The balance sheet data are reported to the national central banks within the general framework of the ECB's money and banking statistics. For institutions subject to full reporting requirements, the balance sheet data referring to the end of a given calendar month are used to determine the reserve base for the maintenance period starting in the calendar month two months later. For example, the reserve base calculated from the balance sheet of the end of February would be used to calculate the reserve requirements to be fulfilled by counterparties in the maintenance period beginning in April.

\section{The reporting framework for the ECB's money and banking statistics includes} the possibility of relieving small institutions of some of the reporting burden. Institutions to which this provision applies only need to report a limited set of balance sheet data on a quarterly basis (as end-of-quarter data) and with a reporting deadline which is longer than that set for larger institutions. For these institutions, the balance sheet data reported for a specific quarter are used to determine, with a lag of two months, the reserve base for the consecutive three reserve maintenance periods. For example, the balance sheet of the end of the first quarter-March - would be valid for the calculation of the reserve base for the maintenance periods beginning in June, July and August.

\section{According to Council Regulation (EC) No 2531/98, the ECB is entitled to include} liabilities resulting from the acceptance of funds together with liabilities resulting from off-balance-sheet items in the reserve base of institutions. In the Eurosystem's minimum reserve system, only the liability categories "deposits" and "debt securities issued" are actually included in the reserve base (see Box).

\section{Liabilities vis-à-vis other institutions included in the list of institutions subject}

to the Eurosystem's minimum reserve system and liabilities vis-à-vis the ECB and the national central banks are not included in the reserve base. In this respect, for the liability category "debt securities issued," the issuer needs to be able to prove the actual amount of these instruments held by other institutions subject to the Eurosystem's minimum reserve system in order to be entitled to deduct them from the reserve base. If such proof cannot be presented, issuers may apply a standardized deduction of a fixed percentage ${ }^{40}$ to this balance sheet item.

\section{The reserve ratios are determined by the ECB subject to the maximum limit} specified in Council Regulation (EC) No 2531/98. The ECB applies a uniform non-zero

\footnotetext{
${ }^{40}$ See Regulation ECB/2003/9. Further information relating to the standardized deduction ratio can be found on the ECB's website (www.ecb.int), as well as on the Eurosystem websites.
} 
reserve ratio to most of the items included in the reserve base. This reserve ratio is specified in Regulation ECB/2003/9. The ECB sets a zero reserve ratio on the following liability categories: "deposits with an agreed maturity of over two years," "deposits redeemable at notice of over two years," "repos," and "debt securities with an agreed maturity of over two years." The ECB may change the reserve ratios at any time. Changes in reserve ratios are announced by the ECB in advance of the first maintenance period for which the change is effective.

\section{Calculation of reserve requirement}

120. The reserve requirement of each individual institution is calculated by applying, to the amount of eligible liabilities, the reserve ratios for the corresponding categories of liabilities. Each institution deducts an allowance of $€ 100,000$ from its reserve requirement in each Member State in which it has an establishment. The granting of such an allowance is without prejudice to the legal obligations of institutions subject to the Eurosystem's minimum reserve system. ${ }^{41}$ The reserve requirement for each maintenance period is rounded to the nearest Euro.

\section{Maintenance period}

\section{The ECB publishes a calendar of the reserve maintenance periods at least three} months before the start of each year. The maintenance period begins on the settlement day of the first main refinancing operation following the meeting of the Governing Council, at which the monthly assessment of the monetary policy stance is pre-scheduled. Under special circumstances, the published calendar may be amended, depending, among other things, on changes in the schedule of Governing Council meetings.

\section{Reserve holdings}

\section{Each institution must hold its minimum reserves on one or more reserve} accounts with the national central bank in the Member State in which it is established. For institutions with more than one establishment in a Member State, the head office is responsible for fulfilling the aggregate minimum reserves of all the domestic establishments of the institution. ${ }^{42}$ An institution with establishments in more than one Member State is

\footnotetext{
${ }^{41}$ For institutions allowed to report statistical data as a group on a consolidated basis according to the provisions of the reporting framework for the ECB's money and banking statistics, only one such allowance will be granted to the group as a whole, unless the institutions provide data on the reserve

base and reserve holdings in a sufficiently detailed manner to enable the Eurosystem to verify their accuracy and quality and to determine the respective reserve requirement of each individual institution included in the group.

${ }^{42}$ If an institution has no head office in a Member State in which it is established, it has to designate a principal branch which would then be responsible for fulfilling the aggregate minimum reserve requirements of all the establishments of the institution in the relevant Member State.
} 
required to hold minimum reserves with the national central bank of each Member State in which it has an establishment, in relation to its reserve base in the corresponding Member State. Institutions' settlement accounts with the national central banks may be used as reserve accounts. Reserve holdings on settlement accounts may be used for intraday settlement purposes. The daily reserve holding of an institution is calculated as the end-of-day balance on its reserve account.

\section{An institution may apply to the national central bank in the Member State in} which the institution is resident for permission to hold all its minimum reserves indirectly through an intermediary. The possibility of holding minimum reserves through an intermediary is, as a rule, restricted to institutions which are constituted in such a way that part of the administration (e.g., treasury management) is normally effected by the intermediary (e.g., networks of savings banks and cooperative banks may centralize their reserve holdings). The holding of minimum reserves through an intermediary is subject to the provisions specified in Regulation ECB/2003/9.

\section{Remuneration of reserve holdings}

124. Holdings of required reserves are remunerated at the average, over the maintenance period, of the ECB's rate (weighted according to the number of calendar days) on the main refinancing operations, calculated using the formula specified in Box 1. Reserve holdings exceeding the required reserves are not remunerated. The remuneration is paid on the second NCB business day following the end of the maintenance period over which the remuneration was earned. 


\title{
Box 1. Reserve Base and Reserve Ratios
}

\author{
A. Liabilities included in the reserve base and to which the positive reserve ratio is applied \\ Deposits $^{1}$ \\ - Overnight deposits \\ - Deposits with an agreed maturity of up to two years \\ - Deposits redeemable at notice up of to two years \\ Debt securities issued \\ - Debt securities with an agreed maturity of up to two years
}

\section{B. Liabilities included in the reserve base and to which a zero reserve ratio is applied}

Deposits $^{1}$

- Deposits with an agreed maturity of over two years

- Deposits redeemable at notice of over two years

- Repos

Debt securities issued

- Debt securities with an agreed maturity of over two years

\section{Liabilities excluded from the reserve base}

- Liabilities vis-à-vis other institutions subject to the Eurosystem's minimum reserve system

- Liabilities vis-à-vis the ECB and the national central banks

1/ Regulation (EC) No 2181/2004 of the European Central Bank of 16 December 2004, amending Regulation (EC) No 2423/2001 (ECB/2001/13) concerning the consolidated balance sheet of the monetary financial institutions sector and Regulation (EC) No 63/2002 (ECB/2001/18) concerning statistics on interest rates applied by monetary financial institutions to deposits and loans vis-à-vis households and non financial corporations (ECB/2004/21) (OJ L 371 of 18 December 2004, page 42), explicitly requires the reporting of deposit liabilities at nominal value. Nominal value means the amount of principal that a debtor is contractually obliged to repay to a creditor. This amendment had become necessary because Council Directive 86/635/EEC of 8 December 1986 on the annual accounts and the consolidated accounts of banks and other financial institutions (OJ L 372 of 31 December 1986, page 1) had been amended to the effect that certain financial instruments could be priced at fair value. 


\section{APPENDIX IV. BANK OF ENGLAND DEFINITION OF ELIGIBLE LiABILITIES}

A summary of the reporting form used by the Bank of England is shown below; more detailed information can be found at http://www.bankofengland.co.uk/statistics/reporters/defs/new2010forms.htm.

The inclusion of these tables is not intended to allow a bank to calculate eligible liabilities, but as an example of a reporting form, the types of liability items which may be included, and where offsets may be made against certain asset items.

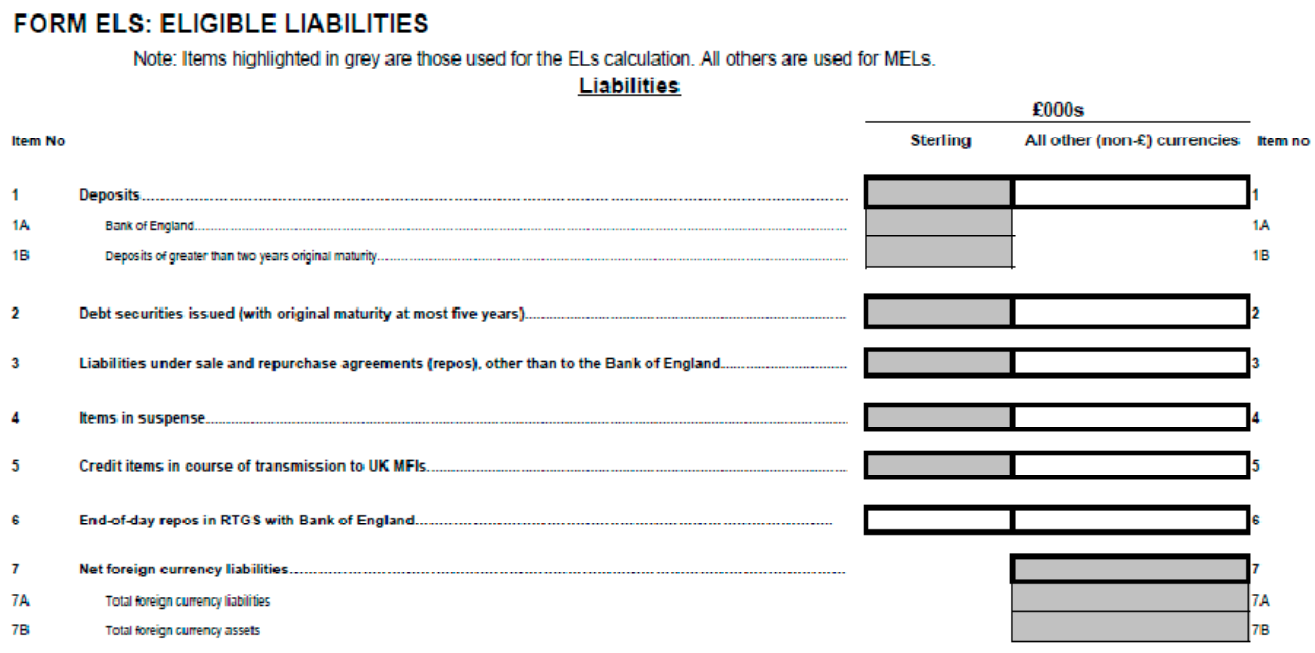




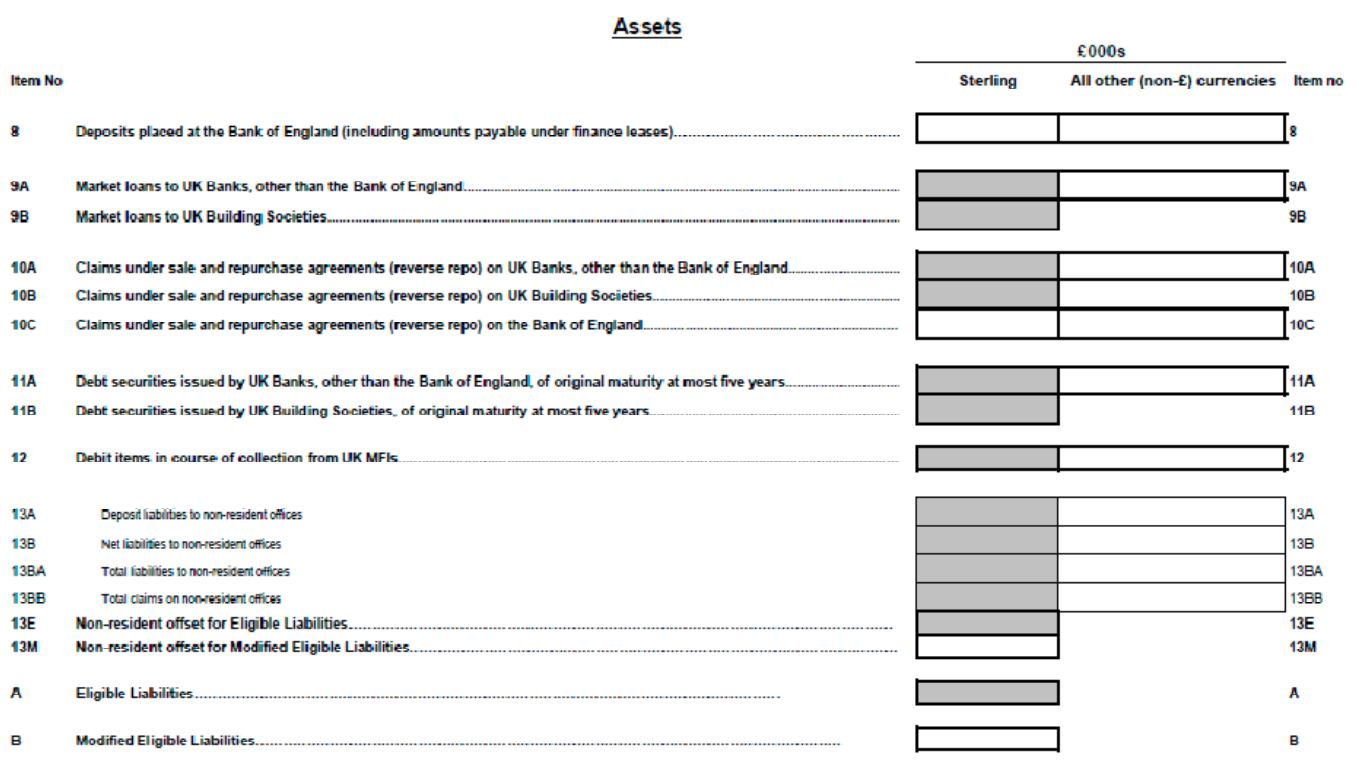

In the calculations below, ' $£$ ' refers to data in the Sterling column and ' $F$ ' to data in the 'All other (non-£) currencies' column.

A

B

\section{Eligible Liabilities}

These should be defined by the following equation:

$(£ 1-£ 1 A-£ 1 B)+£ 2+£ 3+£ 4+0.6^{\star} £ 5+F 7-£ 9 A-£ 9 B-£ 10 A-£ 10 B-£ 11 A-$ $£ 11 \mathrm{~B}-0.6^{*} £ 12-£ 13 \mathrm{E}$

\section{Modified Eligible Liabilities}

These should be defined by the following equation:

$\left(£ 1+£ 2+£ 3+£ 4+0.6^{*} £ 5+£ 6-£ 8-£ 9 A-£ 10 A-£ 10 C-£ 11 A-0.6^{*} £ 12\right)$ $+(1 / 3)^{*}\left(\mathrm{~F} 1+\mathrm{F} 2+\mathrm{F} 3+\mathrm{F} 4+0.6^{*} \mathrm{~F} 5+\mathrm{F} 6-\mathrm{F} 8-\mathrm{F} 9 \mathrm{~A}-\mathrm{F} 10 \mathrm{~A}-\mathrm{F} 10 \mathrm{C}-\mathrm{F} 11 \mathrm{~A}-\right.$ $0.6^{*} \mathrm{~F} 12$ ) - £13M 
APPENDIX V. United STATES RESERVE REQUIREMENTS

\section{Table 5. United States Reserve Requirements-Historical Changes}

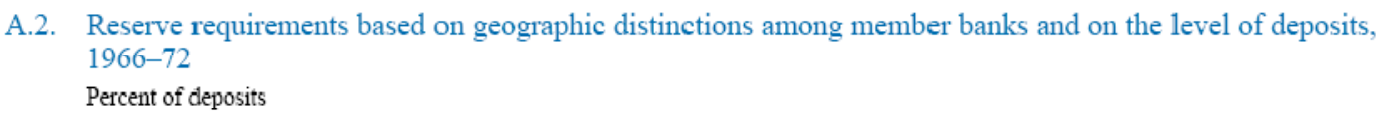

\begin{tabular}{|c|c|c|c|c|c|c|c|}
\hline \multirow{3}{*}{ Effective date } & \multicolumn{4}{|c|}{ Net demand deposits } & \multicolumn{3}{|c|}{$\begin{array}{c}\text { Time deposits } \\
\text { (all classes of banks) }\end{array}$} \\
\hline & \multicolumn{2}{|c|}{$\begin{array}{l}\text { Reserve city banks } \\
\text { (deposit intervals in } \\
\text { millions of dollars) }\end{array}$} & \multicolumn{2}{|c|}{$\begin{array}{l}\text { Country banks } \\
\text { (deposit intervals in } \\
\text { millions of dollars) }\end{array}$} & \multirow[t]{2}{*}{ Savings } & \multicolumn{2}{|c|}{$\begin{array}{c}\text { Other time } \\
\text { (deposit intervals in } \\
\text { millions of dollars) }\end{array}$} \\
\hline & $0-5$ & More than 5 & $0-5$ & More than 5 & & $0-5$ & More than 5 \\
\hline 1966-July 14,21 & 16.5 & 16.5 & 12 & 12 & 4 & 4 & 5 \\
\hline September 8,11 & $\uparrow$ & $\uparrow$ & t & $\uparrow$ & 4 & 4 & 6 \\
\hline 1967-March $2 \ldots \ldots \ldots$ & & & & & 3.5 & 3.5 & $\uparrow$ \\
\hline March $16 \ldots$ & & t & & $\downarrow$ & 3 & 3 & \\
\hline 1968-January $11,18 \ldots$ & $\downarrow$ & 17 & $\downarrow$ & 12.5 & $\uparrow$ & $\uparrow$ & \\
\hline 1969-April $17 \ldots \ldots \ldots$ & 17 & 17.5 & 12.5 & 13 & & & $\downarrow$ \\
\hline 1970-October 1 & 17 & 17.5 & 12.5 & 13 & $\downarrow$ & $\downarrow$ & 5 \\
\hline
\end{tabular}

Source: Reserve Requirements: History, Current Practice, and Potential Reform (1993): Joshua N. Feinman, $F R B$.

\section{Table 6. United States Reserve Requirements-Current Levels}

\begin{tabular}{lcc}
\hline Reserve Requirements & & \\
\hline Net transaction accounts $^{-}$ & 0 & $12-20-07$ \\
$\quad \$ 0$ to $\$ 9.3$ million $^{\underline{2}}$ & 3 & $12-20-07$ \\
$\quad$ More than $\$ 9.3$ million $^{\prime} \$ 43.9$ million $^{\underline{3}}$ & 10 & $12-20-07$ \\
$\quad$ More than $\$ 43.9$ million & 0 & $12-27-90$ \\
Nonpersonal time deposits & & $12-27-90$ \\
Eurocurrency liabilities & 0 & \\
\hline
\end{tabular}

Total transaction accounts consists of demand deposits, automatic transfer service (ATS) accounts, NOW accounts, share draft accounts, telephone or preauthorized transfer accounts, ineligible bankers acceptances, and obligations issued by affiliates maturing in seven days or less. Net transaction accounts are total transaction accounts less amounts due from other depository institutions and less cash items in the process of collection. For a more detailed description, see Form FR 2900 www.federalreserve.gov/boarddocs/reportforms/

Source: Federal Reserve Bank website. 


\section{APPENDIX VI. USE BY CHILE OF RESERVE REQUIREMENTS ON FoREIGN EXCHANGE INFLOWS}

(From "Capital account restrictions in Chile in the 1990s" (IMF, 1999))

[Note that the URR discussed here are imposed on foreign exchange inflows, rather than on the stock of commercial bank liabilities.]

125. [Paragraph 88]. The main instrument for restricting capital flows in Chile has been an unremunerated reserve requirement (URR) on capital inflows. The URR is an indirect, price-based measure in the form of a one-year compulsory deposit of a fraction of capital inflows at the central bank. It is expected to reduce capital inflows by increasing the cost of foreign short-term capital. The URR was to cover all foreign loans except trade credits, but its coverage has been extended over time to non-debt flows as well. It was set initially in 1991 at 20 percent and importers of capital could either make the deposit at the central bank or pay an upfront fee equivalent to the interest cost of the URR. Its implicit cost varies according to the maturity of the inflow. For example, the 30 percent URR has been estimated to increase the cost of borrowing by about 26 percent for one month maturities, or 2 to 3 percentage points for one year maturities (for more details see Cardoso-Laurens 1998 or Le Fort-Sanhueza 1998). Le Fort and Budnevich (1996) note that the expectations of an appreciating exchange rate and high returns to capital in Chile rapidly compensated the costs implicit in the URR especially on portfolio inflows - the financial cost of the LJRR of 1-3 percentage points per annum was easily offset by an expected appreciation the exchange rate. Both coverage and the rate have been subject to change over the decade. The URR was reduced to zero in 1998 in response to more adverse conditions in world financial markets in the aftermath of the Asian crisis.

\section{The main findings and policy implications can be summarized as follows:}

- $\quad$ There are important methodological problems in measuring net inflows and shortterm capital inflows into Chile in many of the studies reviewed which may undermine some of their results on the impact of the URR on capital flows.

- $\quad$ Looking at the evolution of the various components of capital inflows, it seems that the impact of the URR in reducing specific inflows had only a short-term impact before a shift of transactions on the capital account to untaxed inflows occurred.

- $\quad$ Avoidance by migration via the disintermediation of the taxed domestic banking system may have also been important in reducing the effectiveness of the URR.

- $\quad$ One policy implication of capital controls in Chile may be that controls on capital flows are unstable, i.e., they have to evolve over time to counter the dynamic response of optimizing agents. 
127. The studies reviewed conclude that: there is some evidence that the URR has been successful in increasing domestic interest rates; there is a relatively weaker evidence that the URR has reduced the magnitude of capital inflows into Chile and altered the composition of capital inflows in favor of medium- and long-term capital inflows; and there is actually no evidence that the URR affected the level of the real exchange rate.

128. However, the empirical studies reviewed contain econometric problems that may bias their conclusions either in favor or against the hypothesis of effectiveness of controls on capital inflows in Chile. Studies on the effectiveness of the URR in increasing domestic interest rates should control for the impact of the sterilization operations of the monetary authority on domestic real interest rates as part of the increase in interest rates during the life of the URR may have been due to them.

\section{Additional reading}

- $\quad$ Laurens, Bernard and Jaime Cardoso, 1998, "Managing Capital Flows: Lessons from the Experience of Chile,” (unpublished; Washington: MAE Department, International Monetary Fund).

- Le Fort, Guillermo and Carlos Budnevich, 1996, "Capital Account Regulations and Macroeconomic Policy: Two Latin Experiences," The Jerome Levy Economics Institute of Bard College Working Paper No. 162 (Washington: The Jerome Levy Economics Institute of Bard College). 


\section{APPENDIX VII. RESERVE REQUIREMENT LEVELS}

(By Country, 2010)

\begin{tabular}{|c|c|c|c|c|c|c|}
\hline No RR & One RR & $0-5$ & One RR & $6-15$ & One RR & $>15$ \\
\hline Australia & Azerbaijan & 0.5 & Afghanistan & 8 & Bhutan & 16 \\
\hline Canada & Bahrain & 5 & Albania & 10 & Cape Verde & 25 \\
\hline Denmark & Burundi & 3 & Algeria & 8 & Comoros & 25 \\
\hline Mexico & Czech Rep & 2 & Belize & 8.5 & Iraq & 22 \\
\hline New Zealand & ECB & 2 & Chile & 6.6 & Liberia & 15.5 \\
\hline Norway & Georgia & 5 & Costa Rica & 15 & Malawi & 25 \\
\hline Timor Leste & India & 5.75 & ECCB & 6 & Sao Tome \& Principe & 16 \\
\hline \multirow[t]{20}{*}{ United Kingdom } & Kenya & 4.5 & Eritrea & 10 & Bhutan & 25 \\
\hline & Lesotho & 3 & Ethiopia & 15 & Cape Verde & 25 \\
\hline & Malaysia & 1 & Fiji & 7 & Comoros & 22 \\
\hline & Mauritius & 4.5 & Ghana & 9 & Iraq & 15.5 \\
\hline & Mongolia & 5 & Guatemala & 14.6 & Liberia & 25 \\
\hline & Namibia & 1 & Guyana & 12 & Malawi & 24.5 \\
\hline & Nepal & 5.5 & Jordan & 7 & & \\
\hline & Oman & 5 & Moldova & 8 & & \\
\hline & Papua New Guinea & 3 & Morroco & 8 & & \\
\hline & Qatar & 4.75 & Mozambique & 8 & & \\
\hline & Russia & 2.5 & Myanmar & 10 & & \\
\hline & Rwanda & 5 & Philippines & 8 & & \\
\hline & Samoa & 4.5 & Seychelles & 10 & & \\
\hline & Singapore & 3 & Sierra Leone & 12 & & \\
\hline & South Africa & 2.5 & Sri Lanka & 7 & & \\
\hline & Swaziland & 2.5 & Syrian Arab Rep. & 10 & & \\
\hline & Switzerland & 2.5 & Tanzania & 10 & & \\
\hline & The Bahamas & 5 & Uganda & 9.5 & & \\
\hline & Tonga & 5 & Zambia & 8 & & \\
\hline & Vanuatu & 5 & & & & \\
\hline 9 & 29 & & 28 & & 8 & \\
\hline
\end{tabular}




\begin{tabular}{|c|c|c|c|c|c|}
\hline Range of RR & $0-5$ & Range of RR & $5-15$ & Range of RR & $>15$ \\
\hline Bangladesh & $(2.5-5)$ & Argentina & $(0-20)$ & Angola & $(30-100)$ \\
\hline BCEAO & $(3-9)$ & Armenia & $(8-12)$ & Brazil & $(4-42)$ \\
\hline Belarus & $(0-6)$ & Bolivia & $(2-12)$ & Kuwait & $(10-100)$ \\
\hline Bulgaria & $(0-10)$ & Cambodia & $(5-12)$ & Lebanon & $(15-25)$ \\
\hline Colombia & $(0-11)$ & China & $(14-16)$ & Paraguay & $(15-21)$ \\
\hline Iceland & $(0-2)$ & Dominican Republic & $(10-17)$ & Serbia & $(10-100)$ \\
\hline Indonesia & $(1-7.5)$ & Egypt & $(10-14)$ & Suriname & $(25-33)$ \\
\hline Israel & $(0-6)$ & Honduras & $(6-12)$ & & \\
\hline Japan & $(0.05-1.3)$ & Iran & $(10-17)$ & & \\
\hline Kazakhstan & $(0-2.5)$ & Jamaica & $(1-14)$ & & \\
\hline Korea & $(0-7)$ & Macedonia & $(10-20)$ & & \\
\hline Lao & $(2-5)$ & Pakistan & $(0-20)$ & & \\
\hline Poland & $(0-3)$ & Peru & $(6-30)$ & & \\
\hline Saudi Arabia & $(4-7)$ & Romania & $(0-25)$ & & \\
\hline Thailand & $(0.2-6)$ & Tajikistan & $(7-9)$ & & \\
\hline Tunisia & (1-7.5) & Trinidad \& Tobago & $(2-17)$ & & \\
\hline \multirow[t]{7}{*}{ Ukraine } & $(0-4.7)$ & Turkey & $(5-9)$ & & \\
\hline & & United Arab Emirates & $(1-14))$ & & \\
\hline & & United States & $(0-10)$ & & \\
\hline & & Uruguay & $(9-12)$ & & \\
\hline & & Uzbekistan & $(910-15)$ & & \\
\hline & & Vietnam & $(1-12)$ & & \\
\hline & & Yemen & $(7-20)$ & & \\
\hline 17 & & 23 & & 7 & \\
\hline
\end{tabular}

Source: IMF survey of central banks. 